\title{
Kinoa Ununun ve Kısmi Pişirilerek Dondurma Yönteminin Glutensiz Ekmek Kalitesi Üzerine Etkisi
}

\author{
Fatma HAYIT $^{1 *}$, Hülya GÜL ${ }^{2}$ \\ ${ }^{1}$ Bozok Üniversitesi, Gıda İşleme Bölümü, Yozgat, Türkiye \\ ${ }^{2}$ Süleyman Demirel Üniversitesi, Mühendislik Fakültesi, Gıda Mühendisliği Bölümü, Isparta, Türkiye
}

"Sorumlu Yazar: fatma.hayit@bozok.edu.tr

Geliş Tarihi: 15.11 .2019

Kabul Tarihi: 09.12.2019

\section{$\ddot{O} z$}

$\mathrm{Bu}$ çalışmada; farklı oranlarda $(\% 5,10,20$ ve \%30) kinoa unu içeren ve kısmi pişirilerek dondurma yöntemiyle üretilen glutensiz ekmeklerin 0, 5, 10, 15, 30, 45 gün depolanması sonrasında. bazı kimyasal, fiziksel, tekstürel ve duyusal kalite kriterlerinin incelenmesi amaçlanmıştır. Glutensiz un formülasyonu olarak; \%53.15 pirinç unu, \%24.53 nohut unu, \%12.32 patates nişastası, \%5 mısır unu ve \%5 mısır nişastası karışımı kullanılmıştır. Analiz sonuçlarına göre; kinoa unu ilavesi ekmek örneklerinin protein ve toplam diyet lif miktarlarını etkilemezken, nem, kül, kalsiyum (Ca), magnezyum $(\mathrm{Mg})$ ve fosfor $(\mathrm{P})$ miktarları ile sertlik, sakızımsılık ve çiğnenebilirlilik gibi tekstürel değerlerini arttırmıştır. Renk değerlerinden parlaklık $\left(\mathrm{L}^{*}\right)$ değeri azalmış, kırmızılık $\left(\mathrm{a}^{*}\right)$ değeri artmış, sarılık $\left(\mathrm{b}^{*}\right)$ değeri ise değişiklik göstermemiştir. Depolanan glutensiz ekmeklerde sertlik ve sakızımsılık artarken, elastikiyet ve esneklik azalmıştır. Soğuk depolama ile renk değerlerinde önemli bir değişiklik olmadığı belirlenmiştir. Duyusal analiz sonuçlarına göre; kinoa unu ilavesi ve kısmi pişirerek dondurulup depolama işlemi glutensiz ekmeklerin kabul edilebilirliğini olumlu yönde etkilemiştir. Sonuç olarak kinoa ununun \%30 oranına kadar formülasyona ilave edilmesinin uygun olduğu, ve glutensiz ekmeklerin 45 güne kadar kısmi pişirilerek dondurulup depolanabileceği tespit edilmiştir.

Anahtar Kelimeler: Glutensiz ekmek, Kinoa, Kısmi Pişirilerek Dondurma

\section{The Effect of Quinoa Flour and Part-Baking Frozen Process on Gluten Free Bread Quality}

\begin{abstract}
The purpose of this work was to evaluate the some chemical, physical, textural and sensorial quality of frozen partbaked gluten-free breads (FPB-GFB) which contain different amounts of quinoa flour $(5 \%, 10 \%, 20 \%$ and $30 \%)$ after frozen storage $0,5,10,15,30$ and 45 days. $53.15 \%$ rice flour, $24.53 \%$ chickpea flour, $12.32 \%$ potato starch, $5 \%$ corn flour and 5\% corn starch mixture were used as gluten-free flour formulation. According to the obtained results; The addition of quinoa flour did not affect the protein and total dietary fiber content of FPB-GFB, but increased their moisture, ash, calcium $(\mathrm{Ca})$, magnesium $(\mathrm{Mg})$ and phosphorus $(\mathrm{P})$ amounts and increased textural properties such as firmness, gumminess and chewiness. Among crumb color parameters of FPB-GFB, while brightness (L *) decrease, redness $\left(\mathrm{a}^{*}\right)$ increased, yellowness $(\mathrm{b} *)$ did not showed an important change. Firmness and gumminess of FPB-GFB increased whereas springiness and resilience were decreased during frozen storage. There was no significant change in color values with frozen storage.According to sensorial scores; the addition of quinoa flour and part-baking and frozen storage process had a positive effect on the acceptability of gluten-free breads. As a result, it was found that addition of quinoa flour up to $30 \%$ level was suitable and gluten-free breads could be partially cooked and stored for up to 45 days.
\end{abstract}

Keywords: Gluten free bread, quinoa, frozen part-baked 


\section{Giriş}

Gluten ekmeğin ana kalitesi ve yapısı üzerinde önemli bir bileşendir. Fırıncılıkta gluten formları, glutenin gliadin ile ortak olarak alt mikroskobik ağ yapmak için çapraz bağlanır. Karışıma vizkozite ve genişletilebilirlik ile katkıda bulunurlar. Hamurda maya, fermantasyonla karbondioksit gazı üretir. Bu gaz, gluten ağı tarafından tutularak hamurda ve ekmeklerde istenen hacim artışını sağlar (Alvarenga ve ark., 2011).

Çölyak hastalığı ise, gluten içeren besinlerin alınmasıyla ortaya çıkan bağırsak mukozasının hastalığıdır (Gren ve Jabri, 2003; İşleroğlu ve ark., 2009; Villancacci ve ark., 2011). Buğday, çölyak hastalığı için en imünojenik proteine sahip olan tahıl ürünüdür (Nehra ve ark., 2013). Glutenin varlığı mukoza hasarının yenilenmesine yol açmaktadır (Fasano ve Catassi, 2001). Glutene ek olarak patojenik mikroorganizmalar, gluten giriş zamanı, emzirme gibi çevresel tetikleyiciler hastalığın gelişimi için önemli olmaktadır (Koehler, 2014). Hastalığın tedavisi ise sıkı bir glutensiz diyet uygulaması gerektirmektedir (Fasano ve Catassi, 2001; Gallagher ve ark., 2004; İşleroğlu ve ark., 2009; Özuğur ve Hayta, 2011; Nehra ve ark., 2013; Rinaldi ve ark., 2017). Glutenin elimine edilmesi ile tam mukozal iyileşme gerçekleşir (Fasano ve Catassi, 2001). Glutensiz gıdalar sadece çölyak hastaları için değil, aynı zamanda gluten duyarlılığından muzdarip kişiler ve yaşam tarzı ile glutenden kaçınan kişilerin glutensiz bir diyet uygulamak istediği için de gereklidir (Masure ve ark., 2016).

Tahıllar ve sağlık incelendiği zaman nüfusun önemli bir yüzdesi çölyak hastaları gibi gluten alımına intölerans göstermektedir. Çölyak hastalığında vücudun bağışıklık sistemi, gluten için anormal tepkiler vermektedir. Bu durum ince bağırsağın inflamasyonuna yol açarak bağırsakta demir, kalsiyum, A, D, E, K ve folat gibi çeşitli mineral ve vitaminlerin emiliminin azalmasına sebep olur (Rosell ve Garzon, 2015). Tanısı konulan çölyak hastalarının en büyük sorunu, tedavinin gerçekleşebilmesi için glutensiz diyete uyum sağlamada yaşadıkları problemlerdir. Glutensiz diyet karmaşık, zor ve hastaları bunaltıcı bir süreçtir. Glütensiz diyet yapan hastalarınen zorlandıkları kısım kaliteli glutensiz gıda temininde yaşanmaktadır (Masure ve ark., 2016).

Çölyak hastaları için üretilen ticari ürünler nişasta bazlı olduğu için bu ürünlerin diyet lif, mineral madde ve protein gibi besin içeriklerinin zenginleştirilmesi gerekmektedir. Ayrıca, üretilen ürünlerin tazeliğinin korunması için farklı çalışmalara ihtiyaç duyulmaktadır. Özellikle glutensiz ekmek üretiminde tüketiciye, taze ürünün arzının gerçekleştirilmesi gerekmektedir (Hayıt, 2018).

Bu çalışmada çölyak hastalarına yönelik olarak optimizasyon çalışması ile oluşturulan protein ve diyet lif içeriği yüksek glutensiz ekmek formülasyonu (Gül ve Hayıt, 2017) kullanılmıştır. Bu formülasyona (un formülasyonu ile yer değiştirme prensibine göre \%5, 10, 20 ve \%30) kinoa unu ilave edilerek kısmi pişirilerek dondurma işlemi uygulanmıştır. Kısmi pişirme işlemi gören 
glutensiz ekmekler dondurulup 0,5, 10, 15, 30, 45 gün süre ile depolanarak süreç sonlarında çözdürülüp tekrar pişirilip ekmek özelliklerindeki değişimler incelenmiştir.

\section{Materyal ve Metot}

\subsection{Materyal}

Patates nişastası ve mısır nişastası, Tat İnşaat Sanayi ve Ticaret A.Ş'den (İzmir, Turkey); Misır unu, nohut unu, pirinç unu, Hüsnü Özmen Gıda Sanayi A.Ş’den (İzmir, Turkey) temin edilmiştir. Kinoa unu, Dimyat marka olarak Bora Tarım Ürünleri Gıda San. ve Tic Ltd. Şti’den temin edilmiştir. Guar gam ve ksantan gam Selim esans deposu kimyevi maddeler ithalat ve toptan dahili ticaret LTD.ŞTİ'den (İzmir, Turkey) temin edilmiştir. TS 933 (TSE, 1986) yemeklik tuz standartlarına uygun kristal tuz, İçim marka laktozsuz süt, Orkide marka ayçiçek yağı, içilebilir nitelikte çeşme suyu ve yaş ekmek mayası kullanılmıştır. Pişirme kalıbı olarak AACC Metod 1010B (2000)'ye uygun ısıya dayanıklı, iç yüzeyi teflon kaplı, üst uzunluğu $14.3 \mathrm{~cm}$, üst genişliği 7.9 $\mathrm{cm}$, alt uzunluğu $12.9 \mathrm{~cm}$, alt genişliği $6.4 \mathrm{~cm}$ ve derinliği $5.7 \mathrm{~cm}$ ebatlarında galvaniz saçtan özel olarak yaptırılan tavalar kullanılmıştır.

\subsection{Ekmek üretim metodu}

Glutensiz un formülasyonu olarak \%12.32 patates nişastas1, $\% 24.53$ nohut unu, $\% 5$ mısır unu ve \%5 mısır nişastasına ilaveten toplam formülasyon ağırlığı $1000 \mathrm{~g}$ olacak şekilde kalanı pirinç unu ile tamamlanan formülasyon kullanılmıştır. Glutensiz ekmek örnekleri un ağırlığı baz alınarak (1kg); \% 1.5 tuz, \% 3 maya, \%0.5 ksantan gam, \%0.1 guar gam ve \%50 içme suyu, \%10 laktozsuz süt ve \%5 sıv1 yağ ilave edilerek üretilmiştir. Bu bileşenler laboratuvar tipi spiral hamur yoğurma makinesinde (Günsa Endüstriyel Mutfak Ekipmanları, İzmir, Turkey) 5 dk yoğrulmuştur. Oluşan hamur tartılarak $100 \mathrm{~g}$ un esasına göre 10 eşit parçaya bölünmüştür. Pişirme tavasına uygun olacak şekilde elle şekil verilerek pişirme kalıbına alınmıştır. $\% 75 \pm 1$ nem ve $30 \pm 1{ }^{\circ} \mathrm{C}$ sıcaklıkta $60 \mathrm{dk}$. parça fermantasyonunda bekletildikten sonra $220{ }^{\circ} \mathrm{C}$ taş tabanlı, elektrikli, borulu katlı fırında (Enkomak, Antalya) 30 dakika pişirilip en az bir saat boyunca soğutularak analize alınmıştır. Bu glutensiz ekmekler “Kontrol-2” ekmeği olarak adlandırılmıştır. Kısmi pişirilecek glutensiz ekmekler ise parça fermantasyonundan sonra aynı fırında $220{ }^{\circ} \mathrm{C}$ 'de 15 dakika pişirilip oda şartlarında soğutularak polietilen poşetlere alınmıştır. Poşetli ekmekler -20 derecedeki derin dondurucuda belirlenen depolama günleri $(1,5,10,15,30$ ve 45) süresince depolanmıştır. Her bir depolama süresi sonunda kısmi pişirilmiş ekmekler $20^{\circ} \mathrm{C}^{\prime}$ de 30 dakika bekletilerek çözdürülmüş ve 
ardından $220{ }^{\circ} \mathrm{C}^{\prime} \mathrm{de}$ elektrikli fırında $15 \mathrm{dk}$ süreyle pişirilmiştir. Glutensiz ekmeklerin glutenli normal ekmek unundan yapılan ekmekler ile karşılaştırılabilmesi amacıyla glutenli buğday ekmeği de üretilmiş ve bu ekmek örnekleri "Kontrol-1" olarak adlandırılmıştır. Kontrol-1 üretiminde AACC Metot 10-10.03 (AACC 2001) bazı modifikasyonlar uygulanarak kullanılmıştır. Ekmek örnekleri; un ağırlığı baz alınarak \% 1.5 tuz, \% 3 yaş maya, ve farinografta (Brabender, Duisburg, Germany) belirlenen su absorpsiyonuna uygun miktarda içme suyu kullanılarak üretilip, laboratuvar tipi spiral hamur yoğurma makinesinde (Günsa Endüstriyel Mutfak Ekipmanları, İzmir) yoğrulmuştur. Yoğurma sonrası hamur \% $\quad 65-70$ nem ve $25 \pm 1{ }^{\circ} \mathrm{C}$ 'de 30 dakika kitle fermantasyonunda bekletildikten sonra havası alınarak 100 gr un esasına göre 10 eşit parçaya bölünmüştür. $\mathrm{Bu}$ hamurlara, pişirme tavasına uygun olacak şekilde şekil verilmiştir. Hamurlar pişirme kalıbına alınarak 1.5 saat \% 65-70 nem ve $25 \pm 1$ derece sıcaklıkta parça fermantasyona bırakılmıştır. 1. gün analizleri yapılacak ekmekler (Kontrol-1) 260 derece firında 15 dakika süreyle pişirilmiştir. Kısmi pişirilecek örnekler ise parça fermantasyonundan sonra aynı fırında 10 dakika pişirilip oda şartlarında soğutularak polietilen poşetlere alınmıştır. Poşetli ekmekler -20 derecedeki derin dondurucuda belirlenen depolama günleri $(1,5,10,15,30$ ve 45) süresince depolanmıştır. Her bir depolama süresi sonunda kısmi pişirilmiş ekmekler $20^{\circ} \mathrm{C}^{\prime}$ de 30 dakika bekletilerek çözdürülmüş ve ardından $260{ }^{\circ} \mathrm{C}$ 'de elektrikli fırında $5 \mathrm{dk}$ süreyle pişirilmiştir. Tüm ekmek örneklerine uygulanan sıcaklık ve süre değerler ön denemeler ile belirlenmiştir.

Normal buğday unu ile üretilen (Kontrol-1) ekmeklerinde, glutensiz un formülasyonu ile üretilen glutensiz ekmek örneklerinde (Kontrol-2) ve glutensiz ekmek unu formülasyonuna farklı oranlarda kinoa ilave edilerek $(\% 5,10,20$ ve \%30) üretilen örneklerde aşağıda belirtilen analizler yapılmıştır. Tüm analizler üçer tekerrürlü olarak gerçekleştirilmiştir.

\subsection{Ekmek üretiminde kullanılan hammaddelerde yapılan analizler}

Patates nişastası, nohut unu, mısır unu, pirinç unu, mısır nişastasında, nem (AACC Method 44-01.01), kül (AACC Method 08-01.01), ham protein (AACC Metod 46-30.01) ve yağ (AOAC, 1990) analizleri yapılmıştır.

Kinoada, nem (AACC Method 44-01.01), kül (AACC Method 08-01.01), ham protein (AACC Metod 46-30.01), yağ (AOAC, 1990), toplam diyet lif (AACC Metod 37-07.01) ve mineral madde (EPA 6010 ) analizleri yapılmıştır. 


\subsection{Ekmeklerde yapılan analizler}

Kimyasal analizler: Ekmek örneklerinde nem AACC Method 44-01.01, kül AACC Method 08-01. 01, protein AACC Metod 46-30.01, diyet lif AACC Method 32-07.01'a uygun olarak, mineral madde analizi ise EPA 6010 metoduna uygun olarak Perkin Elmer OPTIMA 5300 DV ICP OES cihazı kullanılarak yapılmıştır.

Tekstürel analizler: Ekmekler pişirildikten ve 2 saat süreyle oda sıcaklığında soğutulduktan sonra elektrikli ekmek bıçağı ile $25 \mathrm{~mm}$ kalınlığında dilimlenmiştir. Ortadaki iki dilim Tekstür profil analizleri (TPA) için kullanılmıştır. TPA'leri tekstür analiz cihazında (TA-XT2, Stable Micro Systems, Surrey, UK) 36 mm çapındaki silindirik prob kullanılarak yapılmıştır. Tekstür analiz cihazının test parametreleri; ön test hızı: $1 \mathrm{~mm} \mathrm{sn-1,} \mathrm{test} \mathrm{hızı:} 1.7 \mathrm{~mm} \mathrm{sn-1}$, son test hızı: $10 \mathrm{~mm}$ sn1, batma derinliği (strain): \% 40 olarak ayarlanmıştır. TPA ile ekmek örneklerinin sertlik, kohesif yapışkanlık, çiğnenebilirlik, elastikiyet ve esneklik gibi tekstürel özellikleri enstrümantal olarak belirlenmiştir.

Spesifik hacim analizi: Ekmek hacmi ekmeğin işgal ettiği boşluktur ve ekmek için önemli bir kalite kriteridir. Ekmeklerin hacimleri kuş yemi ile yer değiştirme prensibine göre her deneme ekmek örneğinden en az 10 ekmek alınarak hesaplanmıştır (Elgün vd., 2002). Spesifik hacim değeri ekmek hacminin ağırlığına bölünmesi ile elde edilmiştir.

Duyusal analizler: Duyusal değerlendirmede kullanılan ölçütler ve "Ekmek Değerlendirme Tablosu” Gül ve ark. (2012)'den yararlanılarak hazırlanmıştır. Hacim, şekil simetri, kabuk rengi, ekmek içi rengi, tekstür, ağızda hissedilen yumuşaklık, koku, aroma, tat, genel kanul edilebilirlik, satın alınabilirlik parametreleri 1-5 arası puanlanmıştır. (1puan: kötü, 2puan: zayıf, 3puan: orta, 4puan: iyi, 5puan: çok iyi) Duyusal değerlendirme öncesinde panelistlere ekmeklerin duyusal değerlendirme kriterleri hakkında bilgi verilmiştir. Rastgele numaralandırılan örnekler en az 10 paneliste ayrı ayrı sunulmuş, bir ekmek örneğinden diğerine geçerken panelistlere soğuk içme suyu verilmiştir.

Renk analizleri: Ekmekte renk tayini; Konica Minolta renk cihazı ile bütün ekmekler üzerinde üç paralelli olarak ölçülmüştür. Renk skalası; L* değeri [(0)Siyah - (100) Beyaz], a* değeri [(+) kırmızı, (-) yeşil] ve b* değeri [(+) sarı, (-) mavi] olarak kullanılmıştır (Elgün vd., 2002).

İstatistik analizleri: Ekmek örneklerinin ölçülen tüm özelliklerine ilişkin olarak elde edilen verilerin varyans analizleri Duncan testine göre yapılmıştır. Analizler için SPSS (Versiyon 22) istatistik paket programından faydalanılarak tesadüf parsellerinde 3 faktörlü deneme deseni kullanılmıştır. 


\section{Bulgular ve Tartışma}

\section{Glutensiz Un Formülasyonunda Kullanılan Bileşenlerin Kimyasal Kompozisyonu}

Glutensiz ekmek üretiminde kullanılan nohut unu, mısır unu, pirinç unu, mısır nişastası ve patates nişastasının nem, kül, yağ, protein ve toplam diyet lif değerlerine ilişkin elde edilen bulgular Tablo 1'de verilmiştir. Tablo 1'den de görülebileceği gibi nohut ununun nem, kül, yağ, protein ve diyet lif değerleri sırasıla; $\% 7.66 \pm 0.00, \% 2.86 \pm 0.07, \% 6.33 \pm 0.06, \% 22.37 \pm 0.17$ ve $\% 13.12 \pm 0.04$ olarak bulunmuştur. Nohut ununun yağ, protein ve diyet lif içeriğinin glutensiz ekmek unu formülasyonunda kullanılan diğer bileşenlere göre önemli oranda yüksek değerlerde olduğu dikkat çekmektedir. Farklı araştırıcılar yapılan çalışmalar (Iqbal ve ark., 2006; Rababah ve ark., 2006; Ulukut, 2010; Arab ve ark., 2010; Kohajdova ve ark., 2011; Hefnawy ve ark., 2012; Mohammed ve ark., 2012; Alifak1, 2013; Fard, 2014; Aguilar ve ark., 2015; Hatipoğlu, 2016; Alvarez ve ark., 2017) incelendiğinde; nohut ununun yağ miktarının \%4.70 ile \%6.01; nem miktarının \%6.09 ile \%11.06; protein miktarının \%19.3 ile \%25.5; kül miktarının \%1.82 ile \%3.60 aralığında ve diyet lif miktarının \%19.3 ile \%25.5 aralığında olduğu bildirilmiştir. Bu çalışmada kullanılan nohut unu bileşenlerinin literatürle uyumlu olduğu belirlenmiştir.

Tablo1. Glutensiz ekmek üretiminde kullanılan nohut unu, mısır unu, pirinç unu, mısır nişastası ve patates nişastasının kimyasal kompozisyonu (\%)

\begin{tabular}{lccccc}
\hline Bileşenler & Yağ & Nem & Protein & Kül & Diyet Lif \\
\hline Nohut unu & $6.33 \pm 0.06$ & $7.66 \pm 0.00$ & $22.37 \pm 0.17$ & $2.86 \pm 0.07$ & $13.12 \pm 0.04$ \\
Mısır unu & $5.15 \pm 0.49$ & $10.22 \pm 0.53$ & $7.14 \pm .0 .04$ & $0.97 \pm 0.00$ & $2.74 \pm 0.09$ \\
Pirinç unu & $1.25 \pm 0.21$ & $8.25 \pm 0.24$ & $7.7 \pm 0.05$ & $0.47 \pm 0.07$ & $0.98 \pm 0.00$ \\
Misır nişastası & $0.815 \pm 0.03$ & $8.83 \pm 0.13$ & $0.25 \pm 0.02$ & $0.15 \pm 0.03$ & $0.006 \pm 0.00$ \\
Patates nişastası & $0.45 \pm 0.31$ & $7.25 \pm 0.30$ & $0.19 \pm 0.13$ & $0.55 \pm 0.01$ & $0.04 \pm 0.02$ \\
\hline
\end{tabular}

Glutensiz ekmek unu formülasyonunda kullanılan misır unu \%5.15 yağ, ve \%2.74 diyet lif içeriği ile nohut unundan sonra bu değerler bakımından ikinci sırada yer almıştır. Mısır ununun protein içeriği \%7.14 olarak tesbit edilmiş olup nohut ununa göre üçte bir oranında daha az olduğu, pirinç unu ile yaklaşık protein içeriğine sahip olduğu, mısır ve patates nişastasına göre daha yüksek oranda protein içerdiği belirlenmiştir. Farklı araştırıcılar tarafından yapılan çalışmalarda; mısır ununun yağ miktarının \%4.1 (Wu ve Miano 2008); nem miktarının \%11.1-18.2; protein miktarının \%4.9-8.94 ve kül miktarının \%0.7-\%1.10 aralığında olduğu (Comai ve ark., 2007; Wu ve Miano 2008; Kılınççeker ve Hepsağ 2010; Hatipoğlu 2016) rapor edilmiştir. Bu bağlamda çalışmamızda elde edilen sonuçlar literatür ile benzerlik göstermektedir.

Pirinç ununun yağ (\%1.25) ve diyet lif (\%0.98) içeriği formülasyonda kullanılan nişastalara göre yüksek, ancak misır ve nohut ununa göre düşük bulunmuştur. Pirinç ununun kimyasal 
kompozisyonu literatür ile uyum içerisindedir. Comai ve ark. (2007), Yarpuz (2011), Torbica ve ark., (2012), Hatipoğlu (2016), Turkut ve ark. (2016), Martinez ve Gomez (2017), Giuberti ve ark. (2018) tarafından yapılan çalışmalarda; pirinç ununun yă̆ miktarı \%1.11-0.44; nem miktarı \%8.0116.07; protein miktarı \%6.65-7.94; kül miktarı \%0.26-0.61 aralığında; Giuberti ve ark., 2018 tarafından yapılan bir çalışmada ise diyet lif miktarı \% 1.62 olarak belirlenmiştir.

Formülasyonda kullanılan mısır ve patates nişastasının yă̆, protein ve diyet lif içeriklerinin nohut, mısır ve pirinç ununa göre oldukça düşük olduğu Tablo 1'den görülmektedir. Yapılan farklı çalışmalarda bu sonuçlara benzer bulgulara ulaşılmıştır. Yarpuz (2011), Ali ve ark. (2014), Hatipoğlu (2016), Przetaczek-Rożnowska (2017); mısır nişastasının yağ miktarının \%0.31-0.69; nem miktarının \%6.06-13.63; protein miktarının \%0.20-0.43 ve kül miktarının \%0.11-0.38 aralığında olduğunu bildirmişlerdir. Patates nişastasının yağ, nem, protein ve kül içeriğinin sirasıyla; \%0.10, \%11.22-18.95, \%0.064-0.08, \%0.21-0.47 aralığında olduğu (Wischmann ve ark., 2007; Turkut ve ark., 2016; Przetaczek-Rożnowska 2017) rapor edilmiştir.

\section{Kinoa Ununun Kimyasal Kompozisyonu}

Glutensiz ekmek formülasyonuna ilave edilen kinoa ununun kimyasal kompozisyonu Tablo 2'de verilmiştir. Çalışmada kinoa ununun nem, kül, protein, yağ ve toplam diyet lif değerleri sirasıyla; \%11.67, \%2.14, \%12.56, \%5.93, \%10.94 olarak; mineral madde miktarları ise fosfor $303.4 \mathrm{mg} / 100 \mathrm{~g}$, kalsiyum $36.80 \mathrm{mg} / 100 \mathrm{~g}$, magnezyum $149.5 \mathrm{mg} / 100 \mathrm{~g}$, çinko $3.1 \mathrm{mg} / 100 \mathrm{~g}$ ve demir $4.5 \mathrm{mg} / 100 \mathrm{~g}$ olarak belirlenmiştir. Literatür incelemesinde kinoa ununun nem değeri \%9.13-14.1 aralığında, kül değeri \%1.77- 3.65, protein değeri \%9.1-16.4 aralığında, yağ değeri\%3.20-8.75 aralığında ve diyet lif değeri \%2.1-16.48 aralığında olduğu belirlenmiştir (Comai ve ark., 2007; Axel ve ark., 2015; Keskin ve Evlice 2015; Rizello ve ark., 2016; Nowak ve ark., 2016; Li ve Zhu 2017).

Tablo 2. Kinoada yapilan kimyasal analizler

\begin{tabular}{lc}
\hline Analizler & Kinoa unu \\
\hline Nem $(\%)$ & $11.67 \pm 0.88$ \\
Kül (\%) & $2.14 \pm 0.16$ \\
Protein (\%) & $12.56 \pm 0.31$ \\
Yağ (\%) & $5.93 \pm 0.25$ \\
Toplam diyet lif (\%) & $10.94 \pm 0.47$ \\
Fosfor (mg/100g) & $303.4 \pm 0.00$ \\
Kalsiyum (mg/100g) & $36.8 \pm 0.00$ \\
Magnezyum (mg/100g) & $149.5 \pm 0.02$ \\
Çinko (mg/100g) & $3.1 \pm 0.00$ \\
Demir (mg/100g) & $4.5 \pm 0.00$ \\
\hline
\end{tabular}


Koziol (1992), tarafından yapılan çalışmada; kinoanın protein miktarı \%16.5, yă̆ \%6.3 olarak, kalsiyum 148.7, demir 13.2, magnezyum 249.6, potasyum 926.7, çinko 4.4 ve fosfor 383.7 $\mathrm{mg} / 100 \mathrm{~g}$ olarak belirlenmiştir. Bu çalışmada kullanılan kinoa ununda bulunan mineral madde miktarı (Tablo 2) bu literatür çalışmasına göre düşük bulunmuştur. Sebebinin çalışmada kabuksuz kinoa unu kullanılmasına bağlı olarak, kinoanın kepek kısmıyla önemli miktarda mineral maddenin ayrılmış olduğu düşünülmüştür.

Iglesias-Puig ve ark. (2015), tarafından yapılan çalışmada; kinoa ununda kül \%2.69, nem $\% 10.3$ ve protein \%11, diyet lif \%6.72, Ca $32.7 \mathrm{mg} / 100 \mathrm{~g}, \mathrm{Fe} 4.65 \mathrm{mg} / 100 \mathrm{~g}, \mathrm{Zn} 5.037 \mathrm{mg} / 100 \mathrm{~g}$ olarak raporlanmıştır. Bu çalışmada kinoa ununda bulunan kalsiyum literatür çalışmasına göre daha yüksek olarak belirlenirken, demir ve çinko miktarlarının düşük olduğu görülmüştür. Bu durumun çalışmalarda kullanılan hammaddeden kaynaklanabileceği düşünülmüştür.

\section{Ekmek örneklerinin kül, protein ve toplam diyet lif değerleri}

Glutensiz ekmeklerin kül, protein ve diyet lif miktarları Tablo 3' de verilmiştir. Ekmek örneklerinin kül miktarları kinoa ilaveli glutensiz ekmeklerde kinoa ilavesine bağlı olarak artış göstermiştir. Benzer olarak Iglesias-Puig ve ark. (2015), tarafından yapılan çalışmada; buğday ununa kinoa unu ilavesiyle kül miktarının arttığı bildirilmiştir.

Tablo 3. Ekmek örneklerinde yapılan kül, protein, diyet lif analiz sonuçları

\begin{tabular}{lccc}
\hline Kinoa Oran1 (\%) & Kül & Protein & Diyet Lif \\
\hline Kontrol-1 & $0.81^{\mathrm{e}}$ & $13.56^{\mathrm{a}}$ & $3.89^{\mathrm{b}}$ \\
Kontrol-2 & $0.76^{\mathrm{e}}$ & $11.48^{\mathrm{b}}$ & $11.06^{\mathrm{a}}$ \\
5 & $0.93^{\mathrm{d}}$ & $11.53^{\mathrm{b}}$ & $11.90^{\mathrm{a}}$ \\
10 & $1.06^{\mathrm{c}}$ & $11.59^{\mathrm{b}}$ & $11.06^{\mathrm{a}}$ \\
20 & $1.40^{\mathrm{b}}$ & $11.73^{\mathrm{b}}$ & $11.36^{\mathrm{a}}$ \\
30 & $1.64^{\mathrm{a}}$ & $11.84^{\mathrm{b}}$ & $11.86^{\mathrm{a}}$ \\
\hline
\end{tabular}

Kontrol-1 gurubu ekmeklerin protein değeri \%13.56 olarak, kontrol-2 ekmeklerinin protein değeri ise $\% 11.48$, glutensiz un formülasyonuna $\% 5, \% 10, \% 20$ ve $\% 30$ kinoa ilavesiyle üretilen ekmeklerin protein değerleri sırasıyla \%11.53, \%11.59, \%11.77, \%11.84 olarak bulunmuştur. Glutensiz un formülasyonuna kinoa ilavesi protein değeri üzerinde sayısal bir artış sağlasa da istatistiki bir etki göstermediği görülmektedir (Tablo 3). Bu çalışmaya benzer olarak Iglesias-Puig ve ark. (2015), tarafından yapılan çalışmada; da buğday ekmeğinde protein miktarı \%13.60 olarak bulunmuştur. Hatipoğlu (2016), tarafindan yapılan bir çalışmada; ekmeklik buğday unundan yapılan ekmeğin protein değeri \%6.50 olarak belirtilirken, glutensiz ekmeklerin protein değerlerinin \%4.324.96 aralığında değiştiği raporlanmıştır. Turkut ve ark. (2016), tarafindan yapılan çalışmada; glutensiz ekmeklerin protein değerleri \%7.65-8.40 olarak belirlenmiştir. İncelenen çalışmalarda glutensiz ekmek örneklerinin protein değerinin yaptığımız çalışmaya göre çok daha düşük olduğu 
görülmektedir. Protein, ekmek kalitesi üzerinde önemli bir role sahiptir. Buğday ununa nohut veya diğer baklagil unlarının ilavesi reolojik özellikleri ve son ürün kalitesi üzerinde önemli bir etkiye sahiptir (Singh ve Ram 1990).

Paciulli ve ark. (2016), tarafindan yapılan çalışmada; iki farklı ticari glutensiz un karışımına $\% 10$ ve \%20 kestane unu ilave edilerek glutensiz un karışımları hazırlanarak ekmek üretilmiştir. Ekmeklerin protein değerleri \%5.4-5.8 olarak belirlenmiştir. Bu çalışmamızda yapılan glutensiz ekmeklerin protein değerinin (\%11.48) litaratürde çalışılmış glutensiz ekmeklerin protein değerinden oldukça yüksek olduğu tespit edilmiştir. Bu durum glutensiz un formülasyonu hazırlanırken formülasyonda nohut unu ve misır unu kullanıldığından dolayı olduğunu düşündürmüştür.

Alencar ve ark. (2015), tarafından yapılan glutensiz ekmeklerde kontrol gruba kinoa ve amarant ilavesinin protein, yağ ve kül içeriğinin artmasına sebep olduğu bildirilmiştir. Bu durumun yaptığımız çalışmayla benzer olduğu görülmüştür. Arab ve ark. (2010), tarafından yapılan çalışmada; buğday ununa nohut unu ilavesiyle yapılan makarna örneklerinde protein, kül ve yăg miktarlarının arttığı bildirilmiştir. Kontrol-2 grubu ekmek örneklerinde diyet lif içeriğinin yüksek olmasının da nohut unu ve mısır unu ile ilgili olduğu düşünülmüştür.

Kontrol-1 grubu ekmeklerin toplam diyet lif miktarları \%3.89 olarak belirlenmiştir. İncelenen çalışmalarda buğday ekmeğinin diyet lif miktarının \%1.15-\%3.80 aralığında olduğu gözlenmiştir (Rodge ve ark., 2012; Rizzello ve ark., 2014; John Don Bosco 2014; Collar ve Angioloni 2014; Erdemir 2015; Mudgil ve ark., 2016; Rizello ve ark., 2016). Yaptığımız çalışmada kontrol-1 grubu ekmeklerin diyet lif miktarı literatür ile benzerlik göstermektedir.

Kontrol-2 ekmeklerinin toplam diyet lif değeri ise \%15.29, glutensiz un formülasyonuna $\% 5$, $\% 10, \% 20$ ve \%30 kinoa ilavesiyle üretilen ekmeklerin diyet lif değerleri sırasıyla \%15.90, \%15.06, \%15.36, \%15.86 olarak bulunmuştur. Kinoa unu ilavesi diyet lif miktarını istatistiki olarak etkilememiştir.

Paciulli ve ark. (2016), tarafından yapılan çalışmada; iki farklı ticari glutensiz un karışımına $\% 10$ ve \%20 kestane unu ilave edilerek glutensiz un karışımları hazırlanarak ekmek üretilmiştir. Ekmeklerin diyet liflerinin 16.9- 17.9 aralığında olduğu \%20 kestane unu ilavesiyle diyet lifin \%17.2 den \%17.9'a yükseldiği belirlenmiştir. Korus ve ark. (2017), tarafindan yapılan çalışmada; glutensiz ekmeklerin toplam diyet lif miktarı \%2.9 (29.3 g/kg) iken \%10 kenevir unu ile \%5.92'ye \%20 kenevir unu ile \%9' a çıktığı belirtilmiştir. Yaptığımız çalışmada kinoa unu ilavesinin diyet lif miktarını istatistiki olarak etkilememesinde formülasyonda kullanılan nohut ununun diyet lif içeriğinin yüksek olması etkili olmuştur. 


\section{Ekmeklerin mineral madde değerleri}

Glutensiz diyet için yapılan çalışmalarda en yaygın mineral madde eksiklikleri kasiyum, demir, magnezyum, fosfor ve çinko olarak belirlenmiştir (Botero-López ve ark., 2011; Caruso ve ark., 2013; Oxentenko ve Murray, 2015). Bu çalışmada da bu durum göz önüne alınarak üretilen glutensiz ekmeklerin mineral madde ( $\mathrm{Ca}, \mathrm{Fe}, \mathrm{Mg}, \mathrm{P}$ ve $\mathrm{Zn}$ ) içerikleri incelenmiştir. Tablo 4'de çalışmada üretilen ekmek örneklerinin mineral madde değerleri verilmiştir. Kontrol-1 gurubu ekmeklerin $\mathrm{Ca}, \mathrm{Fe}, \mathrm{Mg}, \mathrm{P}$ ve Zn değerleri sirasıyla; 0.256, 0.009, 0.297, 0.986, $0.009 \mathrm{mg} / \mathrm{g}$ olarak tesbit edilmiştir. Kontrol-2 ekmeklerinin $\mathrm{Ca}, \mathrm{Fe}, \mathrm{Mg}, \mathrm{P}$ ve $\mathrm{Zn}$ değerleri sırasıyla; 0.521, 0.020, 0.443, 1.424, $0.020 \mathrm{mg} / \mathrm{g}$ olarak belirlenmiştir. Çalışmada Kontrol-2 ekmeklerinin Kontrol-1 ekmeklere göre mineral madde değerlerinin yüksek olduğu belirlenmiştir. Yani glutensiz ekmek üretimi için hazırlanan un karışımından üretilen glutensiz ekmek örneklerinin mineral madde içerikleri normal undan yapılan glutenli ekmeğe göre daha yüksek bulunmuştur. Bu sonuç diyetlerinde besin öğeleri açısından eksiklik çeken çölyak hastaları için olumlu bir katkı sağlayacak niteliktedir. Glutensiz un formülasyonuna artan oranlarda kinoa unu ilavesiyle ise glutensiz ekmek örneklerinin $\mathrm{Ca}, \mathrm{Mg}, \mathrm{P}$ değerleri artmıştır.

Tablo 4. Ekmek örneklerinin mineral madde değerleri $(\mathrm{mg} / \mathrm{g})$

\begin{tabular}{lccccc}
\hline $\begin{array}{c}\text { Kinoa } \\
\text { Oranı (\%) }\end{array}$ & $\mathrm{Ca}$ & $\mathrm{Fe}$ & $\mathrm{Mg}$ & $\mathrm{P}$ & $\mathrm{Zn}$ \\
\hline Kontrol-1 & $0.256 \pm 0.01$ & $0.009 \pm 0.00$ & $0.297 \pm 0.01$ & $0.986 \pm 0.00$ & $0.009 \pm 0.00$ \\
Kontrol-2 & $0.521 \pm 0.00$ & $0.020 \pm 0.00$ & $0.443 \pm 0.00$ & $1.424 \pm 0.00$ & $0.020 \pm 0.00$ \\
5 & $0.474 \pm 0.01$ & $0.016 \pm 0.00$ & $0.487 \pm 0.01$ & $1.460 \pm 0.00$ & $0.017 \pm 0.00$ \\
10 & $0.452 \pm 0.00$ & $0.017 \pm 0.00$ & $0.534 \pm 0.00$ & $1.458 \pm 0.00$ & $0.016 \pm 0.00$ \\
20 & $0.617 \pm 0.01$ & $0.024 \pm 0.00$ & $0.640 \pm 0.01$ & $1.709 \pm 0.00$ & $0.021 \pm 0.00$ \\
30 & $0.636 \pm 0.00$ & $0.021 \pm 0.00$ & $0.753 \pm 0.01$ & $1.688 \pm 0.00$ & $0.021 \pm 0.00$ \\
\hline
\end{tabular}

Karagül ve Ercan (1993), tarafından yapılan çalışmada; Tip 1 (külü \% 0.5), Tip 2 (Külü \%0.77) ve Tip 4 (Külü \%0.84) olmak üzere üç farklı randımanlı un kullanılarak bu unlardan elde edilen mineral madde miktarları belirlenmiştir. Ekmek örneklerinin kalsiyum değerleri sırası ile; 13.55, 15.46, $13.59 \mathrm{mg} / 100 \mathrm{~g}$ olarak; demir değerleri 2.77, 3.24, $3.65 \mathrm{mg} / 100 \mathrm{~g}$ olarak; magnezyum değerleri 20.82, 19.28, $19.33 \mathrm{mg} / 100 \mathrm{~g}$ olarak belirlenmiştir. $\mathrm{Bu}$ çalışmaya göre bizim çalışmamızda buğday ekmeğinin demir içeriği düşük, kalsiyum ve magnezyum ise yüksek olarak belirlenmiştir. Rybicka ve Swiglo (2017), tarafından yapılan çalışmada mısır, pirinç, nohut, karabuğday, yulaf, amarant gibi hammaddelerin, farklı formülasyonla üretilmiş glutensiz ekmeklerin, kalsiyum, potasyum, magnezyum, sodyum, bakır, demir, mangan ve çinko miktarları belirlenmiştir. Farklı formülasyonla üretilen glutensiz ekmeklerin kalsiyum miktarı 7.1-166 mg/100g; potasyum miktarı 74-234 mg/100g; magnezyum miktarı 15-76.3 mg/100g; demir miktarı 0.38-6.89 mg/100g; çinko miktarı ise 0.29-0.99 mg/100g aralığında olduğu bildirilmiştir. 
Çalışmalarda yapılan ekmeklerde bulunan mineral maddelerin miktarlarında farklılıklar görülmektedir. $\mathrm{Bu}$ farklılıklar hammadde içerisindeki mineral içeriğinden veya teknolojik proseslerin farklılıklarından kaynaklanabileceği düşünülmüştür.

\section{Ekmek örneklerinin spesifik hacim değerleri}

Kontrol-1 ekmeklerinin spesifik hacim değeri kontrol-2 örneklerinin ve kinoa ilaveli glutensiz örneklerin spesifik hacminden istatistiki olarak önemli derecede $(\mathrm{P}<0.01)$ yüksek bulunmuştur. Kontrol-2 ekmek örneklerinin ve farklı oranlarda kinoa unu ile yapılan glutensiz ekmek örneklerinin spesifik hacim değerleri arasında istatistiki bir fark görülmemiştir. Benzer olarak Alencar vd. (2015), tarafindan yapılan glutensiz ekmeklerde yalancı tahılların ve tatlandırıcıların etkilerinin değerlendirildiği çalışmada; tatlandırıcı, kinoa ve amarant içeren ekmek örneklerinin spesifik hacim değerlerinin; glutensiz kontrol ekmeğe benzer spesifik hacim değerine sahip olduğu belirlenmiştir. Hatipoğlu (2016), tarafından yapılan çalışmada; buğday ekmeğinin spesifik hacmi $2.92 \mathrm{~cm} 3 / \mathrm{g}$ farklı formülasyonlar ile oluşturulan glutensiz ekmeklerin spesifik hacmi ise 1.66-2.92 cm3/g aralığında değiştiği belirlenmiştir. Iglesias-Puig vd. (2015), tarafından yapılan çalışmada; 100 g buğday unu ile yer değiştirme prensibine göre $25 \mathrm{~g}$ ve $50 \mathrm{~g}$ kinoa ilave edilerek ekmek üretilmiştir. Çalışma sonucunda kinoa ilavesinin ekmeklerde ekmek spesifik hacim değerlerini 4.48$3.46 \mathrm{~cm} 3 / \mathrm{g}$ 'den $2.63 \mathrm{~cm} 3 / \mathrm{g}$ 'a düşürdüğü bildirilmiştir.

Yılmaz ve Doğan (2015), tarafından Türkiye piyasasından 8 farklı tahıl bazlı glutensiz ekmeklik un karışımı temin edilerek üretilerek denemeler yapılmıştır. Kontrol buğday ekmeğinin spesifik hacmi $4.20 \mathrm{ml} / \mathrm{g}$ olarak, glutensiz un karışımlarından yapılan örneklerin spesifik hacimleri 2.08- $2.89 \mathrm{ml} / \mathrm{g}$ olarak belirlenmiştir. Wronkowska vd. (2013), tarafından yapılan çalışmada; glutensiz ekmek örneklerinin spesifik hacmi $2.34 \mathrm{ml} / \mathrm{g}$ olduğu bildirilmiştir.

Tablo 5. Ekmek örneklerinin spesifik hacim değerleri $\left(\mathrm{cm}^{3} / \mathrm{g}\right) 1,2$

\begin{tabular}{|c|c|c|c|c|c|c|}
\hline \multirow{2}{*}{$\begin{array}{l}\text { Kinoa } \\
\text { Oranı (\%) }\end{array}$} & \multicolumn{6}{|c|}{ Depolama (Gün) } \\
\hline & 1 & 5 & 10 & 15 & 30 & 45 \\
\hline Kontrol-1 & $2.23^{\mathrm{a}} \mathrm{A}$ & $2.01^{\mathrm{a}}{ }_{\mathrm{B}}$ & $1.96^{\mathrm{a}}{ }_{\mathrm{B}}$ & $1.93^{\mathrm{a}} \mathrm{B}$ & $1.93^{\mathrm{a}} \mathrm{B}$ & $1.86^{\mathrm{a}}{ }_{\mathrm{B}}$ \\
\hline Kontrol-2 & $1.26^{\mathrm{b}} \mathrm{A}$ & $1.18^{\mathrm{b}}{ }_{\mathrm{B}}$ & $1.16^{\mathrm{b}}{ }_{\mathrm{BC}}$ & $1.11^{\mathrm{b}} \mathrm{C}$ & $1.13^{\mathrm{b}}{ }_{\mathrm{BC}}$ & $1.10^{\mathrm{b}} \mathrm{C}$ \\
\hline 5 & $1.26^{\mathrm{b}} \mathrm{A}$ & $1.18^{\mathrm{b}} \mathrm{B}$ & $1.16^{\mathrm{b}}{ }_{\mathrm{BC}}$ & $1.11^{\mathrm{b}} \mathrm{C}$ & $1.12^{\mathrm{b}} \mathrm{C}$ & $1.11^{\mathrm{b}} \mathrm{C}$ \\
\hline 10 & $1.21^{\mathrm{b}} \mathrm{A}$ & $1.16^{\mathrm{b}} \mathrm{B}$ & $1.16^{\mathrm{b}} \mathrm{B}$ & $1.12^{\mathrm{b}} \mathrm{C}$ & $1.11^{\mathrm{b}} \mathrm{C}$ & $1.09^{\mathrm{b}} \mathrm{C}$ \\
\hline 20 & $1.20^{\mathrm{b}} \mathrm{A}$ & $1.17^{\mathrm{b}} \mathrm{AB}$ & $1.16^{\mathrm{b}} \mathrm{AB}$ & $1.13^{\mathrm{b}}{ }_{\mathrm{BC}}$ & $1.12^{\mathrm{b}}{ }_{\mathrm{BC}}$ & $1.10^{\mathrm{b}} \mathrm{C}$ \\
\hline 30 & $1.21^{\mathrm{b}} \mathrm{A}$ & $1.17^{\mathrm{b}} \mathrm{AB}$ & $1.15^{\mathrm{b}} \mathrm{ABC}$ & $1.11^{\mathrm{b}} \mathrm{BC}$ & $1.11^{\mathrm{b}}{ }_{\mathrm{BC}}$ & $1.09^{\mathrm{b}} \mathrm{C}$ \\
\hline
\end{tabular}

Kısmi pişirilerek dondurulmuş ekmeklerin ilk günden sonra spesifik hacim değerleri azalmış fakat depolama süresinin artışıyla bu değer istatistiki olarak sabit kalmıştır. Farklı çalışmalarda belirlenen kontrol ekmekleri ve glutensiz ekmek örneklerinin spesifik hacminin bizim 
çalışmamızdan farklı olmasının un kalitesi, un formülasyonu, fermantasyon ve pişirme süresi ile sıcaklık farklılıkları gibi birçok parametrenin farklı olmasından kaynaklanabileceğini düşündürmektedir.

\section{Ekmek örneklerinin doku profil analiz (TPA) değerleri}

Farklı günlerde depolanan kısmi pişirilerek dondurulmuş glutensiz ekmeklerin ve kontrol ekmeklerinin sertlik değerleri Tablo 5'te verilmiştir. 1. gün en düşük sertlik değerini Kontrol-1 (484.20 g), en yüksek sertlik değerini ise (34769.92 g) \%30 kinoa ilaveli glutensiz ekmek örnekleri almıştır. Kontrol-2 örneklerinde sertlik değeri Kontrol-1 ekmeklerine göre istatistiki olarak önemli $(\mathrm{P}<0.01)$ oranda artmıştır. Glutensiz un formülasyonuna artan oranlarda kinoa unu ilavesi ile glutensiz ekmek örneklerinin sertlik değerleri önemli oranda artış göstermiştir. Hem glutensiz hem de glutenli ekmek örneklerinin kısmi pişirilerek depolanması ile ilerleyen depolama süresi boyunca sertlik değerlerinde önemli oranda artış tesbit edilmiştir. Depolama süresi ile kinoa ilaveli ekmek örneklerinde sadece 45 gün sonunda sertlik istatistiki olarak önemli $(\mathrm{P}<0.01)$ oranda artarken kontrol-1 ekmeklerinde 5 gün depolama ile sertlik artışı olduğu gözlenmiştir.

Tablo 6. Ekmek örneklerinin sertlik değerleri (g)1,2

\begin{tabular}{lcccccc}
\hline Kinoa & \multicolumn{5}{c}{ Depolama (Gün) } \\
\cline { 2 - 7 } Oran1 (\%) & 1 & 5 & 10 & 15 & 30 & 45 \\
\hline Kontrol-1 & $484.20^{\mathrm{d}}{ }_{\mathrm{D}}$ & $887.25^{\mathrm{c}}{ }_{\mathrm{C}}$ & $1002.87^{\mathrm{c}}{ }_{\mathrm{C}}$ & $1208.98^{\mathrm{c}}{ }_{\mathrm{BC}}$ & $1444.51^{\mathrm{b}}{ }_{\mathrm{AB}}$ & $1644.52^{\mathrm{b}}{ }_{\mathrm{A}}$ \\
Kontrol-2 & $23237.10^{\mathrm{c}}{ }_{\mathrm{C}}$ & $24159.62^{\mathrm{b}}{ }_{\mathrm{C}}$ & $27192.23^{\mathrm{b}}{ }_{\mathrm{BC}}$ & $27739.33^{\mathrm{b}}{ }_{\mathrm{BC}}$ & $34054.01^{\mathrm{a}}{ }_{\mathrm{B}}$ & $50036.48^{\mathrm{a}}{ }_{\mathrm{A}}$ \\
5 & $27833.61^{\mathrm{bc}}{ }_{\mathrm{B}}$ & $30087.84^{\mathrm{ab}}{ }_{\mathrm{B}}$ & $31668.77^{\mathrm{ab}}{ }_{\mathrm{B}}$ & $32792.65^{\mathrm{ab}}{ }_{\mathrm{B}}$ & $34411.10^{\mathrm{a}} \mathrm{B}$ & $51129.05^{\mathrm{a}}{ }_{\mathrm{A}}$ \\
10 & $30221.98^{\mathrm{ab}}{ }_{\mathrm{B}}$ & $30246.28^{\mathrm{ab}}{ }_{\mathrm{B}}$ & $31599.47^{\mathrm{ab}}{ }_{\mathrm{B}}$ & $32300.74^{\mathrm{ab}}{ }_{\mathrm{B}}$ & $34636.17^{\mathrm{a}}{ }_{\mathrm{B}}$ & $52929.69^{\mathrm{a}}{ }_{\mathrm{A}}$ \\
20 & $31725.93^{\mathrm{ab}}{ }_{\mathrm{B}}$ & $32543.91^{\mathrm{a}}{ }_{\mathrm{B}}$ & $33940.13^{\mathrm{ab}}{ }_{\mathrm{B}}$ & $33635.19^{\mathrm{ab}}{ }_{\mathrm{B}}$ & $39445.78^{\mathrm{a}}{ }_{\mathrm{B}}$ & $52112.39^{\mathrm{a}}{ }_{\mathrm{A}}$ \\
30 & $34769.92^{\mathrm{a}}{ }_{\mathrm{B}}$ & $36156.09^{\mathrm{a}}{ }_{\mathrm{B}}$ & $37600.27^{\mathrm{a}}{ }_{\mathrm{B}}$ & $38061.52^{\mathrm{a}}{ }_{\mathrm{B}}$ & $41086.48^{\mathrm{a}}{ }_{\mathrm{B}}$ & $53477.49^{\mathrm{a}}{ }_{\mathrm{A}}$ \\
\hline
\end{tabular}

1: Tabloda aynı sütunda küçük harfle gösterilen değerler arasındaki farklar 0.01 güven sınırına göre önemsizdir ve küçük harfler aynı gün yapılan ekmekler arasındaki istatistiksel farklılıkları belirtmektedir.

2: Tabloda aynı satırda büyük harfle gösterilen değerler arasındaki farklar 0.01 güven sınırına göre önemsizdir ve büyük harfler günler arasındaki istatistiksel farklılıkları belirtmektedir.

Martinez ve ark. (2018), tarafindan yapılan çalışmada; buğday ununa farklı oranlarda (\%45, 60 ve \%70) su ilavesiyle üretilen ekmeklerin sertlik değerleri sırası ile 5329 g, 1225 g, 622 g olarak belirlenmiştir. Buğday ekmeğinin sertlik değeri farklı çalışmalarda $355.30 \mathrm{~g}, 655 \mathrm{~g}, 37.1 \mathrm{~PB}$ (penetrasyon birimi), 9625 g olarak raporlanmıştır (Rizzello ve ark., 2014; Hatipoğlu 2016; Kotancılar ve ark., 1996; Rizello ve ark., 2016). Sertlik değeri aynı un kullanımında su miktarından bile etkilenen önemli bir parametredir (Martinez ve ark., 2018). Yapılan çalışmalarda oldukça farklı çıkması da beklenen bir durumdur.

Çalışmamıza benzer olarak, literatür çalışmaları incelendiğinde buğday unu, glutensiz unlar yada bu unlara ilave edilen farklı katkılar ile yapılan ekmeklerin depolama süresine bağlı olarak sertlik değerlerinin arttı̆̆1 görülmüştür (Barcenas ve Rosell 2006; Onyango ve ark., 2010; Y1lmaz ve Doğan 2015; Öztürk ve ark., 2015; Erdemir 2015; Demiray ve ark., 2015; Paciulli ve ark., 2016; 
Rinaldi ve ark., 2017).Yine çalışmamıza benzer olarak Buresova ve ark. (2017), tarafindan glutensiz ekmeklerin incelendiği çalışmada pirinç ununa kinoa ilavesiyle sertliğin arttığı belirtilmiştir.

Elastikiyet değeri (Tablo 6) ilk gün yapılan ekmekler içinde, Kontrol-1 ekmeklerinde en yüksek değeri alırken (2.46), Kontrol-2 ekmeklerde ve glutensiz formülasyona kinoa ilavesi ile yapılan ekmeklerde bu değer önemli oranda $(p<0.01)$ azalmıştır. Fakat bu ekmeklerin kendi içinde elastikiyet değeri istatistiki olarak önemli ( $>00.01)$ olmamıştır. Depolama süresince elastikiyet değeri tüm ekmek örneklerinde genel olarak azalmıştır. Elastikiyet değeri incelenen araştırmalarda buğday ekmeğinde 0.87-12.03 aralığında (Rizzello ve ark., 2014 Bhol ve John Don Bosco 2014; Hatipoğlu 2016); glutensiz ekmeklerde 0.79-87 aralığında (Onyango ve ark., 2010; Hatipoğlu 2016; Turkut ve ark., 2016; Buresova ve ark., 2017; Martinez ve Gomez 2017) olduğu bildirilmiştir.

Tablo 7. Ekmek örneklerinin elastikiyet değerleri ${ }^{1,2}$

\begin{tabular}{|c|c|c|c|c|c|c|}
\hline \multirow{2}{*}{$\begin{array}{l}\text { Kinoa } \\
\text { Oranı }(\%)\end{array}$} & \multicolumn{6}{|c|}{ Depolama (Gün) } \\
\hline & 1 & 5 & 10 & 15 & 30 & 45 \\
\hline Kontrol-1 & $2.46^{\mathrm{a}} \mathrm{A}$ & $1.77^{\mathrm{a}} \mathrm{AB}$ & $1.34^{\mathrm{a}} \mathrm{AB}$ & $0.98^{\mathrm{a}}{ }_{\mathrm{B}}$ & $0.94^{\mathrm{a}}{ }_{\mathrm{B}}$ & $0.94^{\mathrm{a}} \mathrm{B}$ \\
\hline Kontrol-2 & $0.73_{\mathrm{A}}^{\mathrm{b}}$ & $0.69^{\mathrm{b}} \mathrm{AB}$ & $0.62^{\mathrm{c}}{ }_{\mathrm{BC}}$ & $0.63^{b}{ }_{B C}$ & $0.60{ }^{\mathrm{b}} \mathrm{C}$ & $0.60^{\mathrm{b}} \mathrm{C}$ \\
\hline 5 & $0.80^{\mathrm{b}} \mathrm{A}$ & $0.69^{\mathrm{b}}{ }_{\mathrm{AB}}$ & $0.70^{\mathrm{bc}} \mathrm{AB}$ & $0.69^{\mathrm{b}}{ }_{\mathrm{AB}}$ & $0.63^{\mathrm{b}}{ }_{\mathrm{B}}$ & $0.59^{\mathrm{b}}{ }_{\mathrm{B}}$ \\
\hline 10 & $0.79^{\mathrm{b}} \mathrm{A}$ & $0.73^{\mathrm{b}} \mathrm{AB}$ & $0.68^{\mathrm{bc}}{ }_{\mathrm{ABC}}$ & $0.67^{b}{ }_{B C}$ & $0.64^{\mathrm{b}}{ }_{\mathrm{BC}}$ & $0.59^{b} \mathrm{C}$ \\
\hline 20 & $0.79^{\mathrm{b}} \mathrm{A}$ & $0.71^{\mathrm{b}} \mathrm{AB}$ & $0.70^{\mathrm{bc}} \mathrm{AB}$ & $0.66^{\mathrm{b}} \mathrm{AB}$ & $0.64^{\mathrm{b}}{ }_{\mathrm{B}}$ & $0.58^{\mathrm{b}}{ }_{\mathrm{B}}$ \\
\hline 30 & $0.80^{\mathrm{b}} \mathrm{A}$ & $0.71^{\mathrm{b}} \mathrm{AB}$ & $0.68^{b c}{ }_{B}$ & $0.68^{\mathrm{b}} \mathrm{B}$ & $0.64^{\mathrm{b}} \mathrm{C}$ & $0.61^{\mathrm{b}} \mathrm{C}$ \\
\hline
\end{tabular}

1: Tabloda aynı sütunda küçük harfle gösterilen değerler arasındaki farklar 0.01 güven sınıına göre önemsizdir ve küçük harfler aynı gün yapılan ekmekler arasındaki istatistiksel farklılıkları belirtmektedir.

2: Tabloda aynı satırda büyük harfle gösterilen değerler arasındaki farklar 0.01 güven sınırına göre önemsizdir ve büyük harfler günler arasındaki istatistiksel farklılıkları belirtmektedir.

Kohezif yapışkanlık değeri ilk gün yapılan ekmekler incelendiğinde, Kontrol-1 ekmeklerinde en yüksek olurken Kontrol-2 ekmek örneklerinde bu değer önemli oranda $(p<0.01)$ azalmıştır. Depolama süresine bağlı olarak Kontrol-1 ekmeklerinde kohezif yapışkanlık değeri azalmıştır. Kinoalı ve kinoasız glutensiz ekmek örneklerinde 5. günden sonra depolama süresinin uzaması kohezif yapışkanlık değerinde önemli olmamıştır.

Tablo 8. Ekmek örneklerinin kohezif yapışkanlık değerleri ${ }^{1,2}$

\begin{tabular}{|c|c|c|c|c|c|c|}
\hline \multirow{2}{*}{$\begin{array}{l}\text { Kinoa } \\
\text { Oranı }(\%)\end{array}$} & \multicolumn{6}{|c|}{ Depolama (Gün) } \\
\hline & 1 & 5 & 10 & 15 & 30 & 45 \\
\hline Kontrol-1 & $0.87^{\mathrm{a}}{ }_{\mathrm{A}}$ & $0.81^{\mathrm{a}}{ }_{\mathrm{B}}$ & $0.82^{\mathrm{a}}{ }_{\mathrm{B}}$ & $0.81^{\mathrm{a}}{ }_{\mathrm{B}}$ & $0.76^{\mathrm{a}}{ }_{\mathrm{C}}$ & $0.76^{\mathrm{a}} \mathrm{C}$ \\
\hline Kontrol-2 & $0.54^{\mathrm{b}}{ }_{\mathrm{A}}$ & $0.41^{\mathrm{b}}{ }_{\mathrm{B}}$ & $0.40^{\mathrm{b}}{ }_{\mathrm{B}}$ & $0.37^{\mathrm{b}}{ }_{\mathrm{B}}$ & $0.34{ }^{\mathrm{b}} \mathrm{B}$ & $0.34^{\mathrm{b}}{ }_{\mathrm{B}}$ \\
\hline 5 & $0.53^{\mathrm{b}}{ }_{\mathrm{A}}$ & $0.46^{\mathrm{b}}{ }_{\mathrm{B}}$ & $0.44{ }^{\mathrm{b}}{ }_{\mathrm{B}}$ & $0.41^{\mathrm{b}}{ }_{\mathrm{B}}$ & $0.40^{\mathrm{b}}{ }_{\mathrm{B}}$ & $0.40^{\mathrm{b}}{ }_{\mathrm{B}}$ \\
\hline 10 & $0.54^{\mathrm{b}} \mathrm{A}$ & $0.49^{\mathrm{b}}{ }_{\mathrm{B}}$ & $0.45^{\mathrm{b}}{ }_{\mathrm{B}}$ & $0.44^{\mathrm{b}}{ }_{\mathrm{B}}$ & $0.43^{\mathrm{b}}{ }_{\mathrm{B}}$ & $0.41^{\mathrm{b}}{ }_{\mathrm{B}}$ \\
\hline 20 & $0.53^{\mathrm{b}} \mathrm{A}$ & $0.48^{\mathrm{b}}{ }_{\mathrm{B}}$ & $0.43^{\mathrm{b}}{ }_{\mathrm{B}}$ & $0.43^{\mathrm{b}}{ }_{\mathrm{B}}$ & $0.43^{b}{ }_{B}$ & $0.43^{b}{ }_{B}$ \\
\hline 30 & $0.54_{\mathrm{A}}^{\mathrm{b}}$ & $0.50^{\mathrm{b}}{ }_{\mathrm{AB}}$ & $0.45^{\mathrm{b}}{ }_{\mathrm{AB}}$ & $0.40^{\mathrm{b}}{ }_{\mathrm{B}}$ & $0.41^{\mathrm{b}} \mathrm{AB}$ & $0.41^{\mathrm{b}} \mathrm{AB}$ \\
\hline
\end{tabular}
yapılan ekmekler arasındaki istatistiksel farklılıkları belirtmektedir. 
2: Tabloda aynı satırda büyük harfle gösterilen değerler arasındaki farklar 0.01 güven sınırına göre önemsizdir ve büyük harfler günler arasındaki istatistiksel farklılıkları belirtmektedir.

İncelenen literatürlerde buğday ekmeğinin kohezif yapışkanlık değeri 0.58, 0.59, 0.002, 0.53 ve 0.77 olarak bildirilmiştir (Rizzello ve ark., 2014; Kittisuban ve ark., 2014; Bhol ve John Don Bosco 2014; Erdemir 2015; Hatipoğlu 2016). Glutensiz ekmekler için ise 0.001-0.82 aralığında olduğu belirtilmiştir (Onyango ve ark., 2010; Hatipoğlu 2016; Turkut ve ark., 2016; Rinaldi ve ark., 2017; Martinez ve Gomez 2017). Çalışmamıza benzer olarak bazı literatür çalışmalarında ekmek örneklerinin yapışkanlık değerinin depolama sürecinde azaldığı bildirilmiştir (Erdemir 2015; Demiray ve ark., 2015; Paciulli ve ark., 2016; Rinaldi ve ark., 2017).

Yapılan çalışmada ve incelenen literatür çalışmalarında depolamanın kohezif yapışkanlığı azalttığı, glutensiz ekmek örneklerinde bu değerin ekmeklik buğday unundan daha düşük değerler aldığı belirlenmiştir. Formülasyonda glutenin azalması kohezif yapışkanlık değerini azalttığı gözlemlenmiştir.

Çiğnenebilirlik değeri için (Tablo 8) ilk gün ekmekleri incelendiğinde en yüksek çiğnenebilirlik değerini \%30 kinoa ilaveli ekmek örneklerinin aldığı görülmüştür. Kontrol-2 ekmeklerinde çiğnenebilirlik değeri kinoa ilaveli glutensiz ekmek örneklerine göre daha azdır. En düşük çiğnenebilirlik değerini ise Kontrol-1 ekmek örnekleri almıştır. Kontrol-1 grubu ekmeklerde depolama süresi çiğnenebilirlik değerine etki etmemiştir. Kontrol-2 grubu ekmeklerde en yüksek çiğnenebilirlik değerinin 45 gün sonunda pişirilen ekmeklerde olduğu saptanmıştır. Kinoa ilaveli glutensiz ekmeklerde depolama süresince genel olarak çiğnenebilirlik değeri değişmemiştir.

Tablo 9. Ekmek örneklerinin çiğnenebilirlik değerleri $(\mathrm{g})^{1,2}$

\begin{tabular}{|c|c|c|c|c|c|c|}
\hline \multirow{2}{*}{$\begin{array}{l}\text { Kinoa } \\
\text { Oranı }(\%)\end{array}$} & \multicolumn{6}{|c|}{ Depolama (Gün) } \\
\hline & 1 & 5 & 10 & 15 & 30 & 45 \\
\hline Kontrol-1 & $1040.70^{c}{ }_{A}$ & $1187.49^{\mathrm{c}} \mathrm{A}$ & $1024.56^{\mathrm{b}} \mathrm{A}$ & $1322.79^{\mathrm{b}}{ }_{\mathrm{A}}$ & $1027.01^{\mathrm{b}} \mathrm{A}$ & $1201.40^{\mathrm{b}}{ }_{\mathrm{A}}$ \\
\hline Kontrol-2 & $9303.96^{\mathrm{b}}{ }_{\mathrm{B}}$ & $7016.25^{\mathrm{b}}{ }_{\mathrm{B}}$ & $6776.38^{\mathrm{a}}{ }_{\mathrm{B}}$ & $6532.49^{\mathrm{ab}}{ }_{\mathrm{B}}$ & $7119.19^{a}{ }_{B}$ & $10149.63^{\mathrm{a}} \mathrm{A}$ \\
\hline 5 & $11963.31^{\mathrm{ab}} \mathrm{A}$ & $9522.76^{\mathrm{ab}}{ }_{\mathrm{B}}$ & $9726.01^{a}{ }_{B}$ & $9418.52^{\mathrm{a}}{ }_{\mathrm{B}}$ & $8761.56^{\mathrm{a}} \mathrm{B}$ & $11870.22^{\mathrm{a}} \mathrm{A}$ \\
\hline 10 & $12977.66^{\mathrm{ab}}{ }_{\mathrm{A}}$ & $10898.43^{\mathrm{ab}}{ }_{\mathrm{A}}$ & $9778.57^{\mathrm{a}}{ }_{\mathrm{A}}$ & $9641.12^{\mathrm{a}}{ }_{\mathrm{A}}$ & $9721.88^{\mathrm{a}}{ }_{\mathrm{A}}$ & $12962.28^{\mathrm{a}} \mathrm{A}$ \\
\hline 20 & $13462.59^{\mathrm{ab}}{ }_{\mathrm{A}}$ & $11282.00^{\mathrm{b}}{ }_{\mathrm{A}}$ & $10264.23{ }^{\mathrm{a}} \mathrm{A}$ & $9666.19^{\mathrm{a}}{ }_{\mathrm{A}}$ & $10829.58^{\mathrm{a}} \mathrm{A}$ & $12736.10^{\mathrm{a}} \mathrm{A}$ \\
\hline 30 & $15169.35^{\mathrm{a}} \mathrm{A}$ & $12750.20^{\mathrm{b}} \mathrm{A}$ & $11727.95^{\mathrm{a}} \mathrm{A}$ & $10227.41^{\mathrm{a}} \mathrm{A}$ & $10566.38^{\mathrm{a}} \mathrm{A}$ & $13276.22^{a_{A}}$ \\
\hline
\end{tabular}

1: Tabloda aynı sütunda küçük harfle gösterilen değerler arasındaki farklar 0.01 güven sınırına göre önemsizdir ve küçük harfler aynı gün yapılan ekmekler arasındaki istatistiksel farklılıkları belirtmektedir.

2: Tabloda aynı satırda büyük harfle gösterilen değerler arasındaki farklar 0.01 güven sinırına göre önemsizdir ve büyük harfler günler arasındaki istatistiksel farklılıkları belirtmektedir.

Yapılan çalışmada ve incelenen literatür çalışmasında (Rinaldi ve ark., 2017) depolamanın çiğnenebilirlik değerini arttırdığı, glutensiz ekmek örneklerinde bu değerin ekmeklik buğday unundan daha yüksek değerler aldığı belirlenmiştir (Onyango ve ark., 2010; Kittisuban ve ark., 2014; Bhol ve John Don Bosco 2014; Erdemir 2015; Paciulli ve ark., 2016; Buresova ve ark., 2017). 
Esneklik değeri (Tablo 9) ilk gün yapılan Kontrol-1 ekmeklerinde en yüksek değeri (0.57) almıştır. Kontrol-2 ekmek örnekleri ve kinoa ilaveli glutensiz ekmeklerde bu değer Kontrol-1 gruba göre azalmış fakat glutensiz ekmeklerin kendi içinde istatistiki bir fark oluşturmamıştır. Glutensiz un formülasyonuna kinoa ilavesi esneklik değeri için ekmeklerde önemli bir etki göstermemiştir. Depolama süresi tüm ekmek örneklerinde esneklik değerinin azalmasına sebep olmuştur. Kontrol-1 ekmeklerde depolama süresindeki esneklik değerinde ki azalmanın Kontrol-2 ekmek örneklerine göre daha fazla olduğu saptanmıştır.

Tablo 10. Ekmek örneklerinin esneklik değerleri ${ }^{1,2}$

\begin{tabular}{|c|c|c|c|c|c|c|}
\hline \multirow{2}{*}{$\begin{array}{l}\text { Kinoa } \\
\text { Oranı }(\%)\end{array}$} & \multicolumn{6}{|c|}{ Depolama (Gün) } \\
\hline & 1 & 5 & 10 & 15 & 30 & 45 \\
\hline Kontrol-1 & $0.57^{\mathrm{a}} \mathrm{A}$ & $0.50^{\mathrm{a}}{ }_{\mathrm{B}}$ & $0.47^{\mathrm{a}} \mathrm{B}$ & $0.47^{\mathrm{a}} \mathrm{B}$ & $0.40^{\mathrm{a}} \mathrm{C}$ & $0.41^{\mathrm{a}} \mathrm{C}$ \\
\hline Kontrol-2 & $0.28^{\mathrm{b}} \mathrm{A}$ & $0.23^{\mathrm{b}}{ }_{\mathrm{B}}$ & $0.22^{b}{ }_{B}$ & $0.20^{\mathrm{b}}{ }_{\mathrm{B}}$ & $0.19^{\mathrm{b}}{ }_{\mathrm{B}}$ & $0.20^{\mathrm{b}}{ }_{\mathrm{B}}$ \\
\hline 5 & $0.29^{\mathrm{b}} \mathrm{A}$ & $0.23^{\mathrm{b}} \mathrm{AB}$ & $0.22^{b}{ }_{B}$ & $0.22^{b}{ }_{B}$ & $0.21^{\mathrm{b}}{ }_{\mathrm{B}}$ & $0.20^{\mathrm{b}}{ }_{\mathrm{B}}$ \\
\hline 10 & $0.29^{\mathrm{b}} \mathrm{A}$ & $0.25^{\mathrm{b}} \mathrm{AB}$ & $0.22^{\mathrm{b}} \mathrm{AB}$ & $0.21^{\mathrm{b}}{ }_{\mathrm{B}}$ & $0.22^{\mathrm{b}}{ }_{\mathrm{B}}$ & $0.22^{b}{ }_{B}$ \\
\hline 20 & $0.30^{\mathrm{b}} \mathrm{A}$ & $0.24^{\mathrm{b}} \mathrm{AB}$ & $0.22^{\mathrm{b}} \mathrm{AB}$ & $0.21^{\mathrm{b}} \mathrm{B}$ & $0.22^{b}{ }_{B}$ & $0.20^{b}{ }_{B}$ \\
\hline 30 & $0.30^{\mathrm{b}}{ }_{\mathrm{A}}$ & $0.25^{\mathrm{b}} \mathrm{AB}$ & $0.22^{\mathrm{b}}{ }_{\mathrm{B}}$ & $0.22^{\mathrm{b}}{ }_{\mathrm{B}}$ & $0.22^{b}{ }_{B}$ & $0.21^{b_{B}}$ \\
\hline
\end{tabular}

1: Tabloda aynı sütunda küçük harfle gösterilen değerler arasındaki farklar 0.01 güven sınırına göre önemsizdir ve küçük harfler aynı gün yapılan ekmekler arasındaki istatistiksel farklılıkları belirtmektedir.

2: Tabloda aynı satırda büyük harfle gösterilen değerler arasındaki farklar 0.01 güven sinırına göre önemsizdir ve büyük harfler günler arasındaki istatistiksel farkl11ıkları belirtmektedir.

Yapılan çalışmada ve incelenen literatür çalışmalarında depolamanın esneklik değerini azalttığ1 (Onyango ve ark., 2010; Paciulli ve ark., 2016), glutensiz ekmek örneklerinde bu değerin ekmeklik buğday unundan daha düşük değerler aldığı belirlenmiştir (Rizzello ve ark., 2014; Bhol ve John Don Bosco 2014; Rizello ve ark., 2016; Paciulli ve ark., 2016; Buresova ve ark., 2017; Rinaldi ve ark., 2017; Martinez ve Gomez 2017).

\section{Renk analizleri}

Ekmek örneklerinin kabuk rengi L* değeri incelendiğinde (Tablo 10) Kontrol-2 ekmeklerin L* değerinin en yüksek (61.52) olduğu, bu formülasyona kinoa unu ilavesiyle örneklerin kabuk rengi $L^{*}$ değeri kinoa oranına bağlı, istatistiki olarak önemli $(\mathrm{p}<0.01)$ oranda azaldığı belirlenmiştir. Ekmek örneklerinin ilk günkü kabuk rengi L* değerleri dondurulmuş depolama ile değişmemiştir. Dondurma işleminin renk üzerinde etkisi olmadığı düşünüldüğü için bu durum beklenen bir durumdur. 
Tablo 11. Ekmek örneklerinin kabuk rengi L değerleri ${ }^{1,2}$

\begin{tabular}{|c|c|c|c|c|c|c|}
\hline \multirow{2}{*}{$\begin{array}{l}\text { Kinoa } \\
\text { Oranı (\%) }\end{array}$} & \multicolumn{6}{|c|}{ Depolama (Gün) } \\
\hline & 1 & 5 & 10 & 15 & 30 & 45 \\
\hline$\overline{\text { Kontrol-1 }}$ & $56.91^{\mathrm{c}} \mathrm{A}$ & $57.09^{\mathrm{bc}}{ }_{\mathrm{A}}$ & $57.24^{\mathrm{bc}} \mathrm{A}$ & $57.27^{\mathrm{bc}} \mathrm{A}$ & $56.64^{\mathrm{bc}}{ }_{\mathrm{A}}$ & $57.89^{\mathrm{ab}}{ }_{\mathrm{A}}$ \\
\hline Kontrol-2 & $61.52^{\mathrm{a}} \mathrm{A}$ & $62.97^{\mathrm{a}}{ }_{\mathrm{A}}$ & $62.28^{\mathrm{a}}{ }_{\mathrm{A}}$ & $62.63^{\mathrm{a}}{ }_{\mathrm{A}}$ & $61.76^{\mathrm{a}}{ }_{\mathrm{A}}$ & $61.68^{\mathrm{a}} \mathrm{A}$ \\
\hline 5 & $58.78^{\mathrm{b}}{ }_{\mathrm{A}}$ & $58.52^{\mathrm{b}} \mathrm{A}$ & $58.68^{\mathrm{b}}{ }_{\mathrm{A}}$ & $58.33^{\mathrm{b}} \mathrm{A}$ & $58.32^{\mathrm{b}} \mathrm{A}$ & $58.06^{\mathrm{ab}}{ }_{\mathrm{A}}$ \\
\hline 10 & $56.69^{\mathrm{c}}{ }_{\mathrm{A}}$ & $56.53^{\mathrm{bc}}{ }_{\mathrm{A}}$ & $56.73_{\mathrm{A}}^{\mathrm{bc}}$ & $56.48^{\mathrm{bc}}{ }_{\mathrm{A}}$ & $56.83^{\mathrm{bc}} \mathrm{A}$ & $56.37^{\mathrm{b}} \mathrm{A}$ \\
\hline 20 & $54.74_{\mathrm{A}}^{\mathrm{d}}$ & $54.98^{\mathrm{c}}{ }_{\mathrm{A}}$ & $54.60^{\text {cd }}{ }_{A}$ & $55.02^{\mathrm{c}} \mathrm{A}$ & $53.89^{\mathrm{cd}} \mathrm{A}$ & $54.34^{\mathrm{bc}}{ }_{\mathrm{A}}$ \\
\hline 30 & $51.26^{\mathrm{e}}{ }_{\mathrm{A}}$ & $51.79^{\mathrm{d}}{ }_{\mathrm{A}}$ & $51.69^{d}{ }_{A}$ & $51.76^{\mathrm{d}}{ }_{\mathrm{A}}$ & $51.23^{\mathrm{d}}{ }_{\mathrm{A}}$ & $51.03^{\mathrm{c}} \mathrm{A}$ \\
\hline
\end{tabular}

1: Tabloda aynı sütunda küçük harfle gösterilen değerler arasındaki farklar 0.01 güven sınırına göre önemsizdir ve küçük harfler aynı gün yapılan ekmekler arasındaki istatistiksel farklılıkları belirtmektedir.

2: Tabloda aynı satırda büyük harfle gösterilen değerler arasındaki farklar 0.01 güven sınırına göre önemsizdir ve büyük harfler günler arasındaki istatistiksel farklılıkları belirtmektedir.

Buğday unu ile yapılan ekmeklerin kabuk L* değeri incelendiğinde 43.43-98.14 aralığında değerler aldığı görülmüştür (Kotancılar ve ark., 1996; Mohammed ve ark., 2012; Erdemir 2015; Hatipoğlu 2016). Yapılan çalışmalardan anlaşılacağı gibi kullanılan buğday çeşidi, katkı maddesi ve buğday çeşitleri gibi çeşitli faktörler ekmeğinin renk değerini değiştirmektedir.

Glutensiz ekmeklerde $L^{*}$ değerleri 32.89-78.8 aralığında bulunmuştur (Yılmaz ve Doğan 2015; Hatipoğlu 2016; Paciulli ve ark., 2016). Glutensiz ekmeklerde bu değerin farklı çalışmalarda farklı aralıkta çıkması formülasyona ilave edilen maddelerin ve kullanılan miktarlarının farklı olmasından kaynaklanabileceğini düşündürmüştür.

Brito ve ark. (2015), tarafindan yapılan glutensiz kinoa bazlı bisküvilerin besinsel ve duyusal karakterizasyonunun yapıldığı çalışmada; kinoa kullanımının ürünlerde rengin koyulaşmasına sebep olduğu belirtilmiştir. Bu çalışmada da Brito ve ark. (2015), tarafından yapılan çalışmayı destekleyici olarak kinoanın ilavesiyle örneklerin $L^{*}$ değerinin azaldığ

Ekmek örneklerinin kabuk renk değerlerinden a* değeri incelendiğinde (Tablo 11) en yüksek değeri Kontrol-1 ekmeklerinin (8.57) aldığı belirlenmiştir. Bu değere en yakın değeri alan ekmek örnekleri \%20 ve \%30 kinoalı glutensiz ekmekler olmuştur. En düşük değeri ise Kontrol-2 ekmek örnekleri (2.76) almıştır. Dondurulmuş depolama süresi ile ekmek örneklerinin ilk gün aldığı değerler istatistiki olarak ( $\mathrm{p}>0.01)$ önemli oranda değişmemiştir.

Tablo 12. Ekmek örneklerinin kabuk rengi a* değerleri ${ }^{1,2}$

\begin{tabular}{|c|c|c|c|c|c|c|}
\hline \multirow{2}{*}{$\begin{array}{l}\text { Kinoa } \\
\text { Oranı }(\%)\end{array}$} & \multicolumn{6}{|c|}{ Depolama (Gün) } \\
\hline & 1 & 5 & 10 & 15 & 30 & 45 \\
\hline Kontrol-1 & $8.57^{\mathrm{a}} \mathrm{A}$ & $9.18_{\mathrm{A}}^{\mathrm{a}}$ & $9.13^{\mathrm{a}} \mathrm{A}$ & $8.57^{\mathrm{a}} \mathrm{A}$ & $9.11_{\mathrm{A}}^{\mathrm{a}}$ & $8.66^{\mathrm{a}} \mathrm{A}$ \\
\hline Kontrol-2 & $2.76_{\mathrm{A}}^{\mathrm{d}}$ & $2.61_{\mathrm{A}}^{\mathrm{d}}$ & $2.65_{\mathrm{A}}^{\mathrm{d}}$ & $2.55_{\mathrm{A}}^{\mathrm{e}}$ & $2.57_{\mathrm{A}}^{\mathrm{c}}$ & $2.68^{c}{ }_{A}$ \\
\hline 5 & $4.37^{\mathrm{c}} \mathrm{A}$ & $4.12^{\mathrm{c}} \mathrm{A}$ & $4.06^{\mathrm{c}}{ }_{\mathrm{A}}$ & $4.39^{\mathrm{d}}{ }_{\mathrm{A}}$ & $4.20^{\mathrm{bc}} \mathrm{A}$ & $4.30^{\mathrm{bc}} \mathrm{A}$ \\
\hline 10 & $4.62^{\mathrm{c}} \mathrm{A}$ & $4.23^{\mathrm{c}} \mathrm{A}$ & $4.39^{\mathrm{c}} \mathrm{A}$ & $4.56^{\mathrm{cd}}{ }_{\mathrm{A}}$ & $4.88^{\mathrm{bc}}{ }_{\mathrm{A}}$ & $4.23^{\mathrm{bc}}{ }_{\mathrm{A}}$ \\
\hline 20 & $5.32^{\mathrm{b}} \mathrm{A}$ & $5.50^{\mathrm{b}} \mathrm{A}$ & $5.18^{\mathrm{bc}} \mathrm{A}$ & $5.40^{\mathrm{bc}}{ }_{\mathrm{A}}$ & $5.36_{\mathrm{A}}^{\mathrm{b}}$ & $5.43^{\mathrm{b}} \mathrm{A}$ \\
\hline 30 & $5.72^{\mathrm{b}} \mathrm{A}$ & $5.68_{\mathrm{A}}^{\mathrm{b}}$ & $5.82^{\mathrm{b}} \mathrm{A}$ & $5.66_{\mathrm{A}}^{\mathrm{b}}$ & $5.14^{\mathrm{bc}} \mathrm{A}$ & $5.47^{\mathrm{b}} \mathrm{A}$ \\
\hline
\end{tabular}

1: Tabloda aynı sütunda küçük harfle gösterilen değerler arasındaki farklar 0.01 güven sınırına göre önemsizdir ve küçük harfler aynı gün yapılan ekmekler arasındaki istatistiksel farklılıkları belirtmektedir.

2: Tabloda aynı satırda büyük harfle gösterilen değerler arasındaki farklar 0.01 güven sınırına göre önemsizdir ve büyük harfler günler arasındaki istatistiksel farklılıkları belirtmektedir. 
Farklı çalışmalarda buğday ekmeğinin $\mathrm{a}^{*}$ değerinin 0.27-12.73 aralığında (Abasız 2004; Mohammed ve ark., 2012; Dirim ve ark., 2014) glutensiz ekmeklerde ise 2.8-13.81 aralığında olduğu görülmektedir (Çelik ve ark., 1996; Paciulli ve ark., 2016; Hatipoğlu 2016).

Ekmek örneklerinin kabuk renk değerlerinden $b^{*}$ değeri incelendiğinde (Tablo 12) en yüksek değeri Kontrol-1 grubu ekmeklerin (21.13) aldığı belirlenmiştir. Kontrol-1 grubu ekmek örneklerine en yakın değeri \%5 ve \%10 kinoa ilaveli glutensiz ekmek örnekleri almıştır. Ekmek örneklerinin ekmek diş renk $b^{*}$ değeri de depolama süresi ile değişiklik göstermemiştir.

Tablo 13. Ekmek örneklerinin kabuk rengi $b^{*}$ değerleri ${ }^{1,2}$

\begin{tabular}{|c|c|c|c|c|c|c|}
\hline \multirow{2}{*}{$\begin{array}{l}\text { Kinoa } \\
\text { Oranı }(\%)\end{array}$} & \multicolumn{6}{|c|}{ Depolama (Gün) } \\
\hline & 1 & 5 & 10 & 15 & 30 & 45 \\
\hline Kontrol-1 & $21.13^{\mathrm{a}} \mathrm{A}$ & $20.97^{\mathrm{a}} \mathrm{A}$ & $21.03^{\mathrm{a}} \mathrm{A}$ & $20.35^{\mathrm{a}} \mathrm{A}$ & $21.11^{\mathrm{a}} \mathrm{A}$ & $21.10^{\mathrm{a}} \mathrm{A}$ \\
\hline Kontrol-2 & $17.23^{\mathrm{cd}} \mathrm{A}$ & $16.53^{\mathrm{b}} \mathrm{A}$ & $16.38^{\mathrm{c}} \mathrm{A}$ & $16.34^{\mathrm{c}} \mathrm{A}$ & $17.17^{\mathrm{c}} \mathrm{A}$ & $17.30^{\mathrm{b}} \mathrm{A}$ \\
\hline 5 & $18.80^{\mathrm{b}}{ }_{\mathrm{A}}$ & $18.00^{\mathrm{b}} \mathrm{AB}$ & $17.93^{\mathrm{b}} \mathrm{AB}$ & $17.71^{b c}{ }_{B}$ & $18.77^{\mathrm{b}} \mathrm{AB}$ & $17.83^{\mathrm{b}} \mathrm{AB}$ \\
\hline 10 & $18.91_{\mathrm{A}}^{\mathrm{b}}$ & $17.77^{\mathrm{b}} \mathrm{A}$ & $17.53_{\mathrm{A}}^{\mathrm{b}}$ & $17.44^{\mathrm{bc}}{ }_{\mathrm{A}}$ & $17.72^{\mathrm{bc}}{ }_{\mathrm{A}}$ & $17.55^{\mathrm{b}} \mathrm{A}$ \\
\hline 20 & $18.18^{\mathrm{bc}}{ }_{\mathrm{A}}$ & $18.16^{\mathrm{b}}{ }_{\mathrm{A}}$ & $17.87^{\mathrm{b}} \mathrm{A}$ & $18.19^{\mathrm{b}}{ }_{\mathrm{A}}$ & $18.35^{\mathrm{bc}}{ }_{\mathrm{A}}$ & $18.28^{\mathrm{b}} \mathrm{A}$ \\
\hline 30 & $17.72^{\mathrm{bc}}{ }_{\mathrm{A}}$ & $17.12^{\mathrm{b}} \mathrm{A}$ & $17.14^{\mathrm{bc}}{ }_{\mathrm{A}}$ & $17.25^{\mathrm{bc}} \mathrm{A}$ & $17.26^{\mathrm{c}}{ }_{\mathrm{A}}$ & $17.32^{\mathrm{b}} \mathrm{A}$ \\
\hline
\end{tabular}

1: Tabloda aynı sütunda küçük harfle gösterilen değerler arasındaki farklar 0.01 güven sınırına göre önemsizdir ve küçük harfler aynı gün yapılan ekmekler arasındaki istatistiksel farklılıkları belirtmektedir.

2: Tabloda aynı satırda büyük harfle gösterilen değerler arasındaki farklar 0.01 güven sinırına göre önemsizdir ve büyük harfler günler arasındaki istatistiksel farklılıkları belirtmektedir.

Farklı çalışmalarda buğday ekmek kabuğu rengi $b^{*}$ değerinin 2.64-36.7 aralığında (Abasız 2004; Mohammed ve ark., 2012; Dirim ve ark., 2014; Öztürk ve ark., 2015) glutensiz ekmeklerde ise 7.60-27.9 aralığında olduğu görülmektedir (Y1lmaz ve Doğan 2015; Paciulli ve ark., 2016; Hatipoğlu 2016).

\section{Duyusal analizler}

Duyusal analiz sonuçlarından Şekilla, Şekil 1b, Şekil 2a ve Şekil 2b'den de görüleceği gibi hacim, kabuk rengi, tekstür, ağızda hissedilen yumuşaklık, koku, aroma, tat ve genel kabul edilebilirlik değerleri incelendiğinde ilk gün en yüksek değeri Kontrol-1 grubu ekmek örnekleri almıştır. Kontrol-2 ve kinoa ilavesi ile üretilen glutensiz ekmek örnekleri arasında bu parametreler için istatistiki olarak önemli ( $\mathrm{p}>0.01$ ) bir fark olmadığ 1 belirlenmiştir. Kontrol-1 grubu ekmek örnekleri depolama süresince de en yüksek değeri almıştır. Glutensiz ekmek örnekleri arasında hacim, kabuk rengi, tekstür, ağızda hissedilen yumuşaklık, koku, aroma, tat ve genel kabul edilebilirlik değerinin duyusal değerlendirilmesinde genel olarak bir fark görülmediği kinoa unu ilavesinin bu parametre değerleri üzerinde etkili olmadığı, Kontrol-1 gruba göre diğer örneklerin bu değerlendirmelerde daha düşük puanlar aldığı belirlenmiştir. 
Ekmek örneklerinin şekil simetri ve ekmek içi rengi (Şekil 2b) olarak değerlendirildiği durumda tüm ekmek örnekleri şekil simetri ve ekmek içi rengi bakımından aynı puanları almıştır. Tüm ekmekler aynı ölçülerde kalıplar kullanılarak pişirilmiştir. Pişme sırasında herhangi bir şekil değişimi olmadığı için şekil simetri değeri için bu sonuç beklenen bir durumdur.

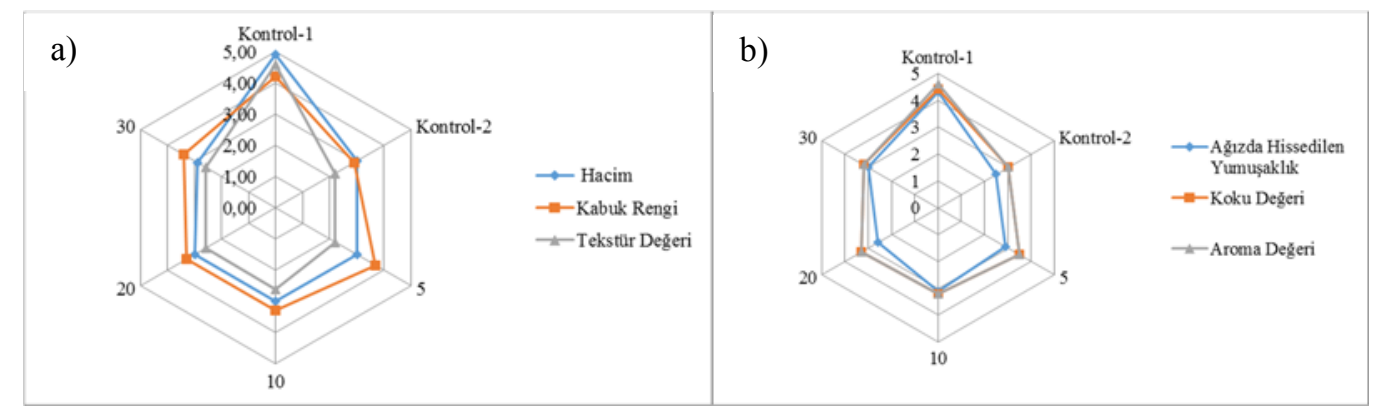

Şekil 1. a) Duyusal değerlendirme (Hacim, kabuk rengi, tekstür değeri), b) Duyusal değerlendirme ( Ağızda hissedilen yumuşaklık, koku ve aroma değeri)
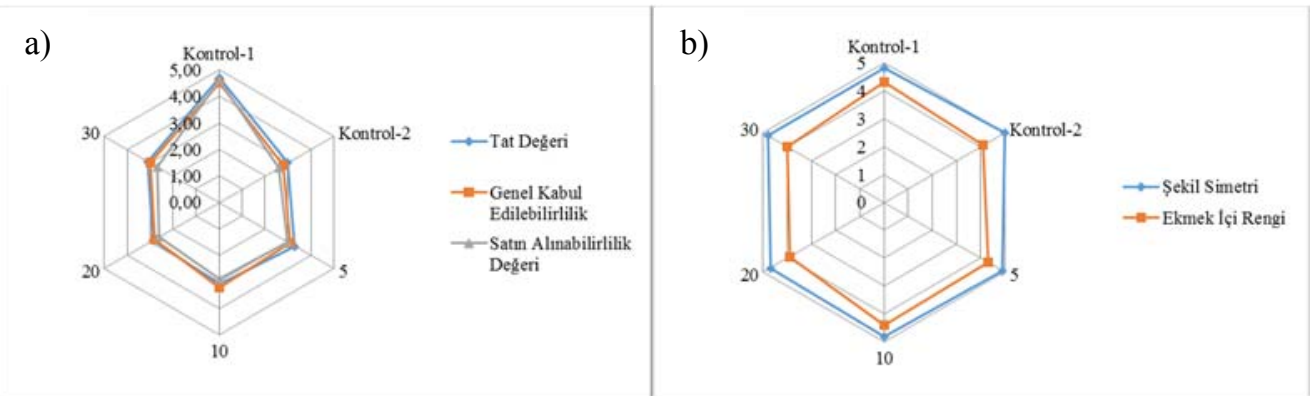

Şekil 2. a) Duyusal değerlendirme (Tat, genel kabul edilebilirlik, satın alınabilirlik), b) Duyusal değerlendirme (Şekil simetri, Ekmek içi rengi)

\section{Sonuçlar ve Öneriler}

Çalışma kapsamında glutensiz ekmek formülasyonuna kinoa unu ilave edilip, elde edilen ekmekler kısmi pişirilerek dondurulmuş ve üretilen ekmeklerin ekmek özellikleri incelenmiştir. Kinoa ilavesi glutensiz ekmeklerin mineral madde değerini ve kül içeriğini arttırmıştır. Tekstürel, renk ve duyusal özelliklere olumsuz bir etki göstermemiştir. Bu yüzden glutensiz ekmeklerin besin içeriğini arttırmak için formülasyona \%30 oranına kadar kinoa ilavesinin yapılabileceği sonucuna varılmıştır. Ayrıca çalışma sonucunda kısmi pişirilerek dondurulan glutensiz ekmeklerin 45 güne kadar kalitelerinde büyük problemler olmadan depolanabileceğine duyusal değerlendirme sonucunda karar verilmiştir. Hastaların en büyük ve önemli sorunlarından olan taze ekmeğe ulaşım probleminin kısmi pişirerek dondurma yöntemi ile çözülebileceği sonucuna varılmıştır. 


\section{Teșekkür}

Bu çalışma TAGEM tarafindan desteklenmiştir. (Proje No: TAGEM-15/AR-GE/47).

\section{Kaynaklar}

Abasız, N. (2004). Ekmek Üretiminde Kullanılan Aktif Soya Ununun Performansını Arttırmada Lipaz ve Glukoz Oksidaz Enzim Katkılarının Etkisi. Yüksek Lisans Tezi, Selçuk Üniversitesi, Fen Bilimleri Enstitüsü, Konya.

Aguilar, N., Albanell, E., Minarro, B., Marta, C. (2015)._Chickpea and Tiger Nut Flours as Alternatives to Emulsifier and Shortening in Gluten-Free Bread. Food Science and Technology, 62, 225-232.

Alencar, N.M.M., Steel, C.J., Alvim, I.D., Morais, E.C., Bolini, H.M.A. (2015). Addition of Quinoa and Amaranth Flour in Gluten-free Breads Temporal Profile and Instrumental Analysis. Food Science and Technology, 62, 1011-1018.

Ali, A., Wani, T.A., Wani, A.I., Masoodi, F.A. (2014). Comparative Study of the Physico-chemical Properties of Rice and Corn Starches Grown in Indian Temperate Climate. Journal of the Saudi Society of Agricultural Sciences, 15, 75-82.

Alifakı, Y.Ö. (2013). Nohut Unu İlavesinin Kekin Dielektrik Özelikleri ve Kalite Parametreleri Üzerine Etkisi. Yüksek Lisans Tezi, Ankara Üniversitesi, Fen Bilimleri Enstitüsü, Ankara.

Alvarenga, N., Lion, F., Belga, E., Motrena, P., Guerreiro, S., Carvalho, J., Canada, H. (2011). Characterization of Gluten-free Bread Prepared From Maize, Rice and Tapioca Flours Using the Hydrocolloid Seaweed Agar-Agar. Recent Research in Science and Technology, 3, 64-68.

Alvarez, M.D., Herranz, B., Campos, G., Canet, W. (2017). Ready-to-Eat Chickpea Flour Puree or Cream Processed by Hydrostatic High Pressure with Final Microwave Heating. Innovative Food Science and Emerging Technologies, 41, 90-99.

Arab, A.A.E., Helmy, I.M.F., Bareh, G.F. (2010). Nutritional Evaluation and Functional Properties of Chickpea (Cicer arietinum L.) Flour and the Improvement of Spaghetti Produced from Its. Journal of American Science, 6(10), 1055-1072.

Axel, C., Röcker, B., Brosnan, B., Zannini, E., Furey, A., Coffey, A., Arendt, E. (2015). Application of Lactobacillus Amylovorus DSM19280 in Gluten-free Sourdough Bread to Improve the Microbial Shelf Life. Food Microbiol, 47, 36-44.

Barcenas, M.E., Rosell, C.M. (2006). Effect of Frozen Storage Time on the Bread Crumb and Aging of ParBaked Bread. Food Chemistry, 95, 438-445.

Bhol, S., Johndonbosco, S. (2014). Influence of Malted Finger Millet and Red Kidney Bean Flour on Quality Characteristics of Developed Bread. Food Science and Technology, 55, 294-300.

Botero,.J.E., Lopez, M., Araya, A., Parada, M.A., Mendez, F., Pizarro, N., Espinosa, P.,Canales, T., Alarcon. , C. (2011). Micronutrient Deficiencies in Patients with Typical and a Typical Celiac Disease. Journal Pediatric Gastroenterol Nutritient, 3, 265-270.

Brito, I.L., Leite de Souza, E., Felex, S.S.S., Madruga, M.S., Yamashita, F., Magnani, M. (2015). Nutritional and Sensory Characteristics of Gluten-Free Quinoa (Chenopodium quinoa Willd)-Based Cookies Development using an Experimental Mixture Design. Journal Food Science Technolgy, 52, 58665873.

Buresova, I., Tokar, M., Maracek, j., Hrivna, L., Famera, O., Sottnikova, V. (2017). The Comparison of the Effect of Added Amaranth, Buckwheat, Chickpea, Corn, Millet and Quinoa Flour on Rice Dough Rheological Characteristics, Textural and Sensory Quality of Bread. Journal of Cereal Science, 75, 158-164.

Caruso, R., Pallone, F., Stasi, E., $\quad$ Romeo, S., $\quad$ Monteleone, G. (2013). Appropriate Nutrient Supplementation in Celiac Disease. Annals of Medicine, 8, 522-531.

Collar, C., Angioloni, A. (2014). Nutritional and Functional Performance of High $\beta$-Glucan Barley Flours in Breadmaking: Mixed Breads Versus Wheat Breads. European Food Research and Technology, 238, 459-469. 
Comai, S., Bertazzo, A., Bailoni, L., Zancato, M., Costa, C.V.L., Allegri, G. (2007). The Content of Proteic and Nonproteic (free and protein-bound) Tryptophan in Quinoa and Cereal Flours. Food Chemistry, $100,1350-1355$.

Çelik, İ., Kotancılar, H.G., Ertugay, Z. (1996). Doğu Anadoluda Yetiştirilen Buğdayların Fiziksel Kimyasal ve Teknolojik Özellikleri ile Ekmeklik Kalitelerinin Belirlenmesi. Atatürk Üniversitesi Ziraat Fakültesi Dergisi, 27 (4), 562-575.

Demiray, E., Çelik, İ., Nogay, O., Tülek, Y. (2015). Denizli Karahöyük Ekmeği Zıgır'ın Renk ve Tekstürel Özellikleri. Akademik Gida, 13, 223-228.

Dirim, S.N., Ergün, K., Çalıskan, G., Özalp, H., Balkesen, N. (2014). Farklı Unların Ekmeğin Kalite Özellikleri Üzerine Etkisi. Akademik Gıda, 12(4), 27-35.

Elgün, A., Ertugay, Z., Certel, M., Kotanc1lar, H.G., 2002. Tahıl ve Ürünlerinde Analitik Kalite Kontrolü ve Laboratuvar Uygulama Kılavuzu. Atatürk Üniversitesi Ziraat Fakültesi Ofset Tesisleri, 245s, Erzurum.

Erdemir, Z.Ş. (2015). Isıl İşlem Görmüş Bakla Ezme Tozunun Ekmek Yapımında Kullanımı ve Kalite Kriterleri Üzerine Etkisinin Belirlenmesi. Yüksek Lisans Tezi, Pamukkale Üniversitesi, Fen Bilimleri Enstitüsü, Denizli.

Fard, E.D. (2014). Köfte Tipi Et Ürünlerinde Emülsiye Edilmiş Zeytin Yağı ve Nohut Unu Kullanımının Ürün Özelliklerine Etkilerinin Araştırılması. Yüksek Lisans Tezi, Ege Üniversitesi, Fen Bilimleri Enstitüsü, İzmir.

Fasano, A., Catassi, C. (2001). Current Approaches to Diagnosis and Treatment of Celiac Disease: an Evolving Spectrum. Gastroenterology, 120, 36-51.

Gallagher, E., Gormley, T.R., Arendt, E.K. (2004). Recent Advances in the Formulation of Gluten-Free Cereal-Based Products. Trends in Food Science and Technology, 15, 143-152.

Giuberti, G., Rocchetti, G., Sigolo, S., Fortunati, P., Lucini, L., Gallo, A. (2018). Exploitation of Alfalfa Seed (Medicago sativa L.) Flour into Gluten-Free Rice Cookies: Nutritional, Antioxidant and Quality Characteristics. Food Chemistry, 239, 679-687.

Gren, P., Jabri, B. (2003). Coeliac Disease. Lancet, 362, 383-391.

Gül, H., Acun, S., Türk, S., Nayır, N., Şen, H. ( 2012). Doğal Antioksidan ve Diyet Lif Kaynağı Olarak Şarap İşletmeleri Atığı Olan Üzüm Posasının Fonksiyonel Ekmek Üretiminde Kullanılabilme Olanaklarının Araştırılması. TAGEM Rapor No: 10/AR-GE/08, 86s.

Gül H., Hayıt F. (2017, May). Optimization of Gluten-Free Bread Formulation by using Response Surface Methodology. Abstract Proceeding Book of International Conference on Agriculture, Forest, Food Sciences and Technologies (ICAFOF 2017) Conference, May 15 - 17, 2017, Cappadocia / Turkey.

Hatipoğlu, S. (2016). Patates Unu ve Gam İlavesinin Glutensiz Ekmek Kalitesi Üzerine Etkileri. Yüksek Lisans tezi, Pamukkale Üniversitesi, Fen Bilimleri Enstitüsü, Denizli.

Hayıt, F. (2018). Çölyak hastalarına yönelik kısmi pişirilerek dondurma yöntemi ile glutensiz ekmek üretimi ve kalitesinin araştırılması. Doktora Tezi, Süleyman Demirel Üniversitesi, Fen Bilimleri Estitüsü, Isparta.

Hefnawy, T.M.H., El-Shourbagy, G.A., Ramadan, M.F. (2012). Impact of Adding Chickpea (Cicer arietinum L.) Flour to Wheat Flour on the Rheological Properties of Toast Bread. International Food Research Journal, 19(2), 521-525.

Iglesias-Puig, E., Monedero, V., Haros, M. (2015). Bread with Whole Quinoa Flour and Bifidobacterial Phytases Increases Dietary Mineral Intake and Bioavailability. Food Science and Technology, 60, 7177.

Iqbal, A., Khalil, I.A., Ateeq, N., Khan, M.S. (2006). Nutritional Quality of Important Food Legumes. Food Chemistry, 97, 331-335.

İşleroğlu, H., Dirim, S., Ertekin, F. (2009). Gluten İçermeyen, Hububat Esaslı Alternatif Ürün Formülasyonları ve Üretim Teknolojileri. Gida, 34, 29-36.

Karagül, M., Ercan, R. (1993). Zenginleştirilmiş Ekmeklerde İşleme ve Depolama Sırasında Bazı Vitamin ve Mineral Madde Miktarlarındaki Değişmeler. Gıda, 18, 357-363.

Keskin, Ş., Evlice, K.A. (2015). Fırın Ürünlerinde Kinoa Kullanımı. Tarla Bitkileri Merkez Araştırma Enstitüsü Dergisi, 24(2), 150-156.

Kılınçarslan, O., Hepsağ, F. (2010). Kaplama Malzemesi Olarak Mısır Unlarının Bazı Kalite Özelliklerinin Belirlenmesi. Gıda Teknolojileri Elektronik Dergisi, 5(2), 20-27.

Kittisuban, P., Ritthiruangdej, P., Suphantharika, M. (2014). Optimization of Hydroxypropylmethylcellulose, Yeast $\beta$ - Glucan, and Whey Protein Levels Based on Physical Properties of Gluten- Free Rice Bread Using Response Surface Methodology. Food Science and Technology, 57, 738-748.

Koehler, P. (2014). Celiac Disease and Gluten. Multidisciplinary Challenges and Opportunities, 1-96. 
Kohajdova, Z., Karovičová, J., Magala, M. (2011). Utilisation of Chickpea Flour for Crackers Production. Acta Chimica Slovaca, 4(2), 98-107.

Korus, J., Witczak, M., Ziobro, R., Juszczak, L. (2017). Hemp (Cannabis sativa subsp. sativa) Flour and Protein Preparation as Natural Nutrients and Structure Forming Agents in Starch Based Glutenfree Bread. Food Science and Technology, 84, 143-150.

Kotancılar, G., Çelik, İ., Ertugay, Z., Elgün, A. (1996). Farklı Ambalajlarda Depolanan Katkılı ve Katkısız Unlarda Meydana Gelen Reolojik ve Ekmek Özelliklerindeki Değişimlerin Belirlenmesi Üzerine Bir Araştırma. Atatürk Üniversitesi Ziraat Fakültesi Dergisi, 27(1), 31-49.

Koziol, M. (1992). Chemical Composition and Nutritional Evaluation of Quinoa (Chenopodium quinoa Willd.). Journal of Food Composition and Analysis, 5, 35-68.

Li, G., Zhu, F. (2017). Physicochemical Properties of Quinoa Flour as Affected by Starch Interactions. Food Chemistry, 221,1560-1568.

Martinez, M.M., Gomez, M. (2017). Rheological and Microstructural Evolution of the Most Common Gluten-Free Flours and Starches During Bread Fermentation and Baking. Journal of Food Engineering, 197, 78-86.

Martinez, M.M., Román, L., Gomez, M. (2018). Implications of Hydration Depletion in the in Vitro Starch Digestibility of White Bread Crumb and Crust. Food Chemistry, 239, 295-303.

Masure, H.G., Fierens, E., Delcour, J.A. (2016). Current and Forward Looking Experimental Approaches in Gluten-Free Bread Making Research. Journal of Cereal Science, 67, 92-111.

Mohammed, I., Ahmed, A.R., Senge, B. (2012). Dough Rheology and Bread Quality of Wheat-Chickpea Flour Blends. Industrial Crops and Products, 36, 196-202.

Mudgil, D., Barak, S., Khatkar, B.S. (2016). Optimization of Bread Firmness, Specific Loaf Volume and Sensory Acceptability of Bread with Soluble Fiber and Different Water Levels. Journal of Cereal Science, 70, 186-191.

Nehra, V., Marietta, E., Murray, J. (2013). Celiac Disease. Encyclopedia of Human Nutrition, 298-306.

Nowak, V., Du, J., Charrondiere, U.R. (2016). Assessment of the Nutritional Composition of Quinoa (Chenopodium quinoa Willd.). Food Chemistry, 193, 47-54.

Onyango, C., Mutungi, C., Unbehend, G., Lindhauer, M.G. (2010). Rheological and Baking Characteristics of Batter and Bread Prepared from Pregelatinised Cassava Starch and Sorghum and Modified Using Microbial Transglutaminase. Journal of Food Engineering, 97, 465-470.

Oxentenko, A.S., Murray, J.A. (2015). Celiac Disease: Ten Things That Every Gastroenterologist Should Know. Clinical Gastroenterology and Hepatology, 8, 1396-1404.

Öztürk, S., Fırat, S., Tutar, A., Dizman, M. (2015). Humik Asitin Ekmek ve Kek Üretiminde Kullanımı. Kahramanmaraş Sütçü İmam Üniversitesi Doğa Bilimleri Dergisi, 1-5.

Özuğur, G., Hayta, M. (2011). Tahıl Esaslı Glutensiz Ürünlerin Besinsel ve Teknolojik Özelliklerinin İyileştirilmesi. Gıda, 36, 287-294.

Paciulli, M., Rinaldi, M., Cirlini, M., Scazzina, F., Chiavaro, E. (2016). Chestnut Flour Addition in Commercial Gluten-Free Bread, A Shelf-Life Study. Food Science and Technology, 70, 88-95.

Przetaczek-Roznowska, I. (2017). Physicochemical Properties of Starches Isolated from Pumpkin Compared with Potato and Corn Starches. International Journal of Biological Macromolecules, 101, 536-542.

Rababah, T.M., Mahasneh, M.A., Ereifej, K.I. (2006). Effect of Chickpea, Broad Bean, or Isolated Soy Protein Additions on the Physicochemical and Sensory Properties of Biscuits. Journal of Food Science, $71,6$.

Rinaldi, M., Paciulli, M., Caligiani, A., Scazzina, F., Chiavaro, E. (2017). Sourdough Fermentation and Chestnut Flour in Gluten-Free Bread: A Shelflife Evaluation. Food Chemistry, 224, 144-152.

Rizzello, C.G., Calasso, M., Campanella, D., Angelis, M.D., Gobbetti, M. (2014). Use of Sourdough Fermentation and Mixture of Wheat, Chickpea, Lentil and Bean Flours for Enhancing the Nutritional, Texture and Sensory Characteristics of White Bread. International Journal of Food Microbiology 180, $78-87$.

Rodge, A.B., Sonkamble, S.M., Salve, R.V., Hashmi, S.I. (2012). Effect of Hydrocolloid (guar gum) Incorporation on the Quality Characteristics of Bread. Journal Food Process Technolgy, 3, 2-7.

Rosell, C.M., Garzon, R. (2015). Chemical Composition of Bakery Products. Handbook of Food Chemistry, $1-28$.

Rybicka, I., Swiglo, A.G. (2017). Minerals in Grain Gluten-Free Products. The Content of Calcium, Potassium, Magnesium, Sodium, Copper, Iron, Manganese, and Zinc. Journal of Food Composition and Analysis, 59, 61-67. 
Singh, P.N., Ram, H. (1990). Effect of Phosphorous and Sulphur Application on Protein and Amino Acid Contents in Chickpea. Indian Journal of Pulses Research, 3, 36-39.

Torbica, A., Hadnadev, M., Hadnadev, T.D. (2012). Rice and Buckwheat Flour Characterisation and Its Relation to Cookie Quality. Food Research International, 48, 277-283.

Turkut, G.M., Çakmak, H., Kumcuoğlu, S., Tavman, S. (2016). Effect of Quinoa Flour on Gluten-Free Bread Batter Rheology and Bread Quality. Journal of Cereal Science, 69,174-181.

Ulukut, K.A.G. (2010). Çerezlik Mısır Hamuruna Nohut Unu, Yerfıstığı Unu Ve Kırmızıbiber Tohum Unu Eklenmesi Sonucu Isıl ve Reolojik Özelliklerde Meydana Gelen Değişimin İncelenmesi. Yüksek Lisans Tezi, İstanbul Teknik Üniversitesi, Fen Bilimleri Enstitüsü, İstanbul.

Villancacci, V., Ceppa, P., Tavani, E., Vindigni, C., Volta, U. (2011). Coeliac Disease: the Histology Report. Digestive and Liver Disease, 43, 385-395.

Wischmann, B., Ahmt, T., Bandsholm, O., Blennow, A., Young, N., Jeppesen, L., Thomsen, L. (2007). Testing Properties of Potato Starch from Different Scales of Isolations A Ringtest. Journal of Food Engineering, 79, 970-978.

Wronkowska, M., Haros, M., Soral-Smietana, M., 2013. Effect of Starch Substitution by Buckwheat Flour on Glutenfree Bread Quality. Food Bioprocess Technolgy, 6, 1820-1827.

$\mathrm{Wu}$, Q., Miano, Y. (2008). Mechanochemical Efects of Micronization on Enzymatic Hydrolysis of Corn Flour. Carbohydrate Polymers, 72, 398-402.

Yarpuz, D. (2011). Glutensiz Ekmek Üzerine Araştırmalar. Yüksek Lisans Tezi, Selçuk Üniversitesi, Fen Bilimleri Estitüsü, Konya.

Yılmaz, Y., Doğan, İ.S. (2015). Glutensiz Ekmek Karışımlarının Kalite ve Bileşenler Yönünden Değerlendirilmesi. Gıda, 40(6), 335-342. 